\title{
Lower-Middle Devonian (upper Emsian-Eifelian, serotinus-kockelianus zones) conodont faunas from the Prague Basin, the Czech Republic
}

\author{
STANISLAVA BERKYOVÁ
}

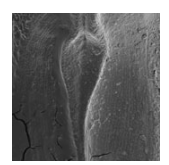

\begin{abstract}
Lower-Middle Devonian conodonts (serotinus-kockelianus zones) from the Třebotov Limestone (Daleje-Třebotov Formation) and Choteč Limestone (Choteč Formation) were studied. The following sections in the Prague Basin were sampled in an attempt to refine the conodont biostratigraphy of this sequence: Barrandov road cut, Prastav quarry at Holyně, Jelínek mill quarry at Chýnice and Červený quarry near Suchomasty. Another aim was to collect new data from sections which have not been sampled before: Na Škrábku quarry at Choteč, U Němců section at Karlštejn and Na vyhlídce section at Hostím. The main focus was on clarifying ranges of individual conodont taxa and thus enabling more precise correlations to be made. Among the most important findings is the lower occurrence of Polygnathus costatus partitus Klapper, Ziegler \& Mashkova (the defining species for the Lower-Middle Devonian boundary), recorded in its regional reference section (Prastav quarry) but $2.2 \mathrm{~m}$ below the previous boundary. The correlation between the onset of the Basal Choteč event, as well as the occurrence of Polygnathus sp. aff. Polygnathus trigonicus, with the base of the costatus Zone is supported by the results of this study. $\bullet$ Key words: Lower-Middle Devonian, conodont biostratigraphy, Prague Basin.
\end{abstract}

BERKYOVÁ, S. 2009. Lower-Middle Devonian (upper Emsian-Eifelian, serotinus-kockelianus zones) conodont faunas from the Prague Basin, the Czech Republic. Bulletin of Geosciences 84(4), 667-686 (10 figures). Czech Geological Survey, Prague. ISSN 1214-1119. Manuscript received June 10, 2009; accepted in revised form November 20, 2009, published online December 18, 2009; issued December 31, 2009.

Stanislava Berkyová, Czech Geological Survey, P.O.B. 85, 11821 Prague 1; berkyova.s@seznam.cz.

Lower-Middle Devonian conodonts from the Prague Basin are the subject of the present research. The interval studied comprises the Třebotov Limestone (Daleje-Třebotov Formation, upper Emsian-lowermost Eifelian) and Choteč Limestone (Choteč Formation, Eifelian) and their shallow-water counterparts (Suchomasty and Acanthopyge limestones). The following sections were sampled (Fig. 1): Barrandov road cut, Prastav quarry at Holyně, Na Škrábku quarry at Choteč, Jelínek mill quarry at Chýnice, U Němců section at Karlštejn, Červený quarry near Suchomasty and Na vyhlídce section at Hostím. These sections were studied within the framework of the author's Ph.D. thesis, which deals with environmental changes that took place close to the Lower-Middle Devonian boundary, the Basal Choteč event. Detailed sampling for biostratigraphic purposes turned out to be a necessity in order to enable global correlations with this event, which has previously been correlated with the base of the costatus Zone, the entry of the goniatite Pinacites jugleri and the boundary of the Nowakia holynensis/N. sulcata zones (Chlupáč \& Kukal 1986). There is a distinct basin-wide change in sedimentation patterns during this time interval with the deposition of light bioturbated skeletal wackstones (Třebotov Limestone) to dark, well washed peloidal grainstones alternating with dark lime mudstone and gray, poorly bioturbated wackstones (Choteč Limestone). The above mentioned sections were sampled in order to refine the existing conodont zonal scheme and to provide new data for sections which have not been sampled previously.

\section{History of conodont studies in the Prague Basin (Lower-Middle Devonian boundary interval)}

The first conodont studies of Lower-Middle Devonian strata from the Prague Basin took place in the 1970s and were focused on sequences from the top of the Zlíchov Formation (Lower Emsian) to the top of the Choteč Limestone (Eifelian), with the emphasis on the position of the Lower-Middle Devonian boundary. The following sections in the Prague Basin had already been studied by preceding authors, especially with respect to Lower-Middle Devonian conodont taxonomy and biostratigraphy: Prastav quarry at Holyně, Jelínek mill quarry at Chýnice, Císařská rokle gorge at Srbsko, Hlubočepy-Vysoká quarry (Klapper 


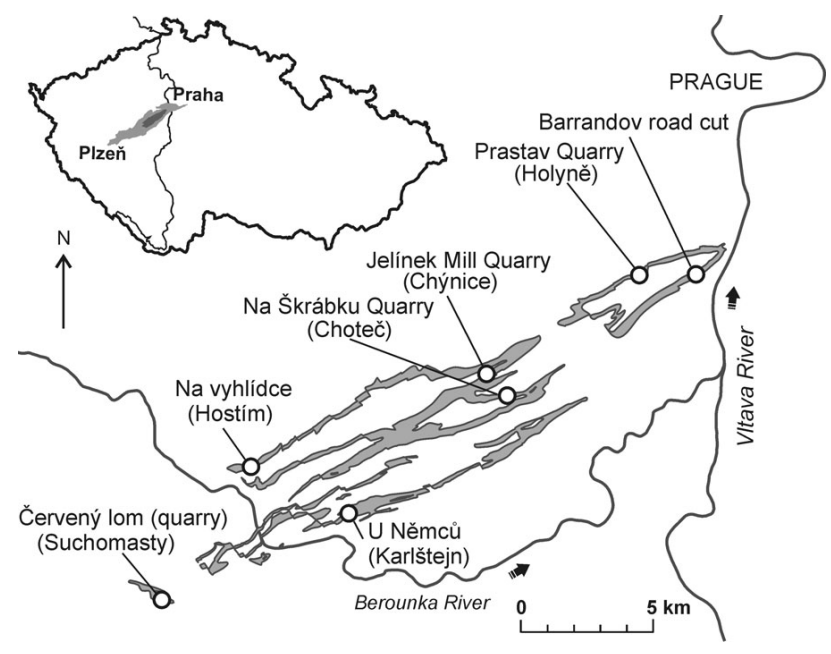

Figure 1. Schematic map showing location of the Prague Basin in the Czech Republic and distribution of the Daleje-Třebotov and Choteč formations with positions marked of sections sampled. Location plan of the Daleje-Třebotov and Choteč formations (marked in grey) is based on geological maps (1: 25 000) published by the Czech Geological Survey.

1977a, Klapper et al. 1978), Hlubočepy-railway cut (Ziegler in Chlupáč et al. 1977), Červený quarry near Suchomasty (Klapper 1977a, Klapper et al. 1978, Weddige \& Ziegler 1987, Kalvoda \& Zikmundová in Galle \& Hladil 1991), Barrandov road-cut section (Zusková 1991), Jirásek quarry (Kalvoda in Hladil \& Kalvoda 1993, Kalvoda \& Zikmundová in Galle \& Hladil 1991) and Preisler quarry in the Koněprusy area (Kalvoda \& Zikmundová in Galle \& Hladil 1991).

\section{Studied sections}

Prastav quarry, Fig. $2 A\left(50^{\circ} 02^{\prime} 0.56^{\prime \prime} N, 14^{\circ} 21^{\prime} 14.9^{\prime \prime} E\right)$. An abandoned quarry situated N of Prague-Holyně. Regional reference section of the Lower-Middle Devonian boundary. Třebotov and the base of the Choteč limestones are well exposed in this section. Relevant papers are: Chlupáč (1959), Klappper (1977), Klapper et al. (1978), Chlupáč et al. (1977), Chlupáč et al. (1979), Chlupáč (1982, 1985), Buggisch \& Mann (2004), Ellwood et al. (2006) and Koptíková (accepted). The following conodont zones have been recognized: serotinus, patulus, partitus, costatus zones. Klapper (1977) and Klapper et al. (1978) provided a first conodont zonation. According to new data, the base of the partitus Zone (Lower-Middle Devonian boundary) lies $5 \mathrm{~m}$ below the base of the Choteč Limestone, which is $2.2 \mathrm{~m}$ lower than the previously reported lowest occurrence of $P$. c. partitus. The first $P$. costatus patulus in this study was found $4.5 \mathrm{~m}$ below the base of the Choteč Limestone, which is $1.5 \mathrm{~m}$ higher than that reported by Klapper (1977). For that reason, the base of the patulus Zone has been drawn according to previously published data at this section. P. c. costatus, which has not been found previously, was recorded $2 \mathrm{~m}$ above the base of the Choteč Limestone. That is in agreement with Klapper et al.'s (1978) study in which Polygnathus sp. aff. $P$. trigonicus was reported $1.75-1.8 \mathrm{~m}$ above the base of the Choteč Limestone (for a discussion on correlation of occurrence of the latter mentioned taxon and the base of the costatus Zone see text below). A correlation between the costatus Zone and the presence of $P$. sp. aff. $P$. trigonicus had been suggested earlier (Klapper et al. 1978, p. 105).

Barrandov road cut, Fig. $2 B\left(50^{\circ} 02^{\prime} 08^{\prime \prime} N\right.$, 14 $\left.23^{\circ} 33^{\prime \prime} E\right)$. The Třebotov Limestone and the base of the Choteč Limestone crop out in this section which was exposed during construction of the main road system in Prague, (Lukeš 1989 and Zusková 1991). Bases of the patulus and the partitus zones were drawn according to data published by Zusková (1991), as occurrences reported in this study are higher. The first occurrence of $P$. c. costatus (two specimens) was reported $1.25 \mathrm{~m}$ below the base of the Choteč Limestone in this study. This is the first record of this taxon below the base of the Choteč Limestone in the Prague Basin. The australis Zone is drawn at this section with a question mark on the basis of the lowest occurrence of $P$. pseudofoliatus. The overlap of the base of the australis Zone and the lowest occurrence of $P$. pseudofoliatus is not completely certain, as a lower range of this taxon cannot be ruled out (see text below). The thickness of rocks corresponding to the costatus Zone would be $3.5 \mathrm{~m}$, which is in contrast to other sections in the Prague Basin; however, there is some evidence for condensed sedimentation in this section. Among these are intervals with hardgrounds and from which a higher number of conodont elements were recovered. Furthermore, in this section the Choteč Limestone is only $6 \mathrm{~m}$ thick, and is overlain by the Srbsko Formation, however, the contact itself is covered and therefore a physical unconformity cannot be ruled out.

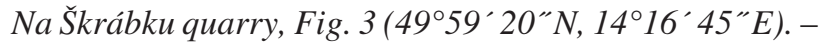
An abandoned quarry situated at the foot of Škrábek hill in the village of Choteč and stratotype of the Choteč Limestone. The Třebotov and Choteč limestones both crop out in this section. Relevant papers are: Chlupáč (1959), Svoboda \& Prantl (1948), Buggisch \& Mann (2004) and Koptíková (accepted). The following conodont zones were recognized (this study): serotinus, patulus, partitus, costatus, australis Zone (the last mentioned zone with a question mark). The first occurrence of $P$. c. partitus (the Lower-Middle Devonian boundary) was documented $3.4 \mathrm{~m}$ below the base of the Choteč Limestone. P. c. costatus was found $5 \mathrm{~m}$ above the base of Choteč Limestone; however, the base of the costatus Zone was drawn according to the occurrence of Polygnathus sp. aff. P. trigonicus 
A

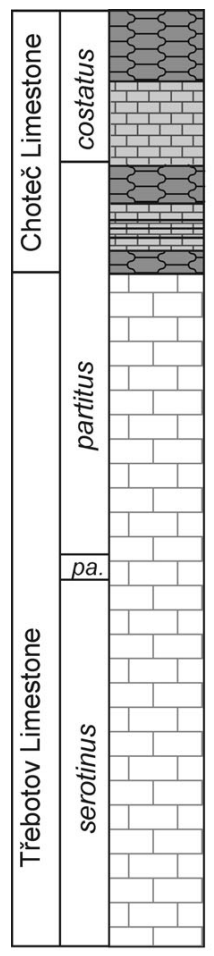

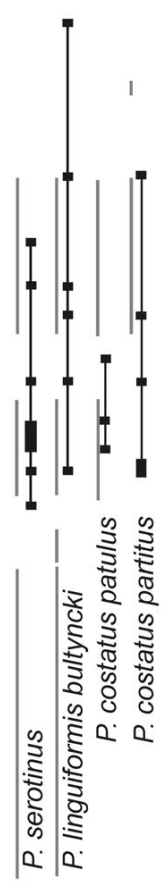

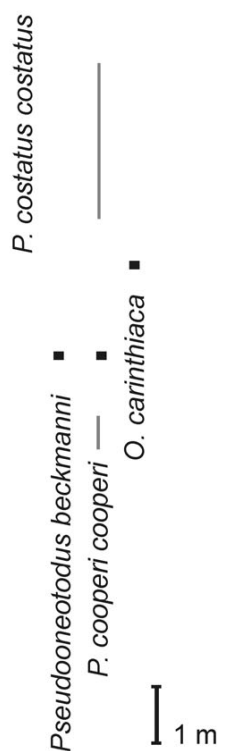

B

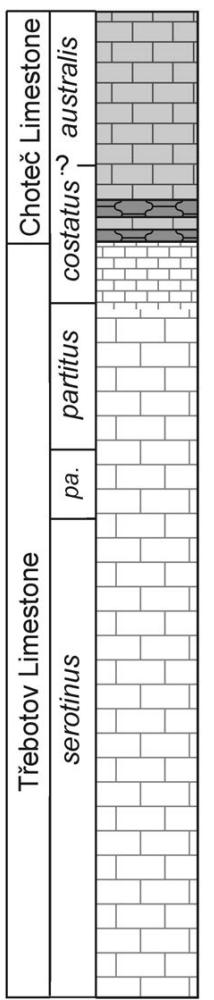

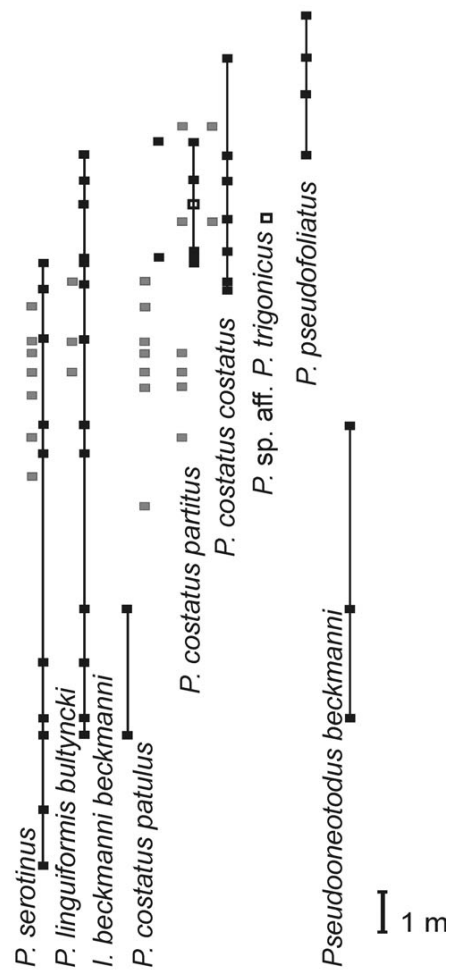

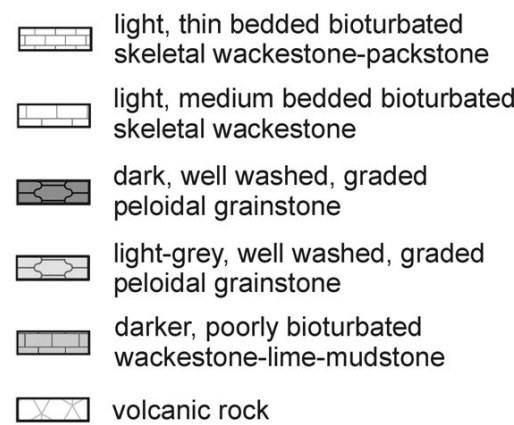

dark, thin-bedded

wackestone-lime-mudstone with chert

bioturbated skeletal wackestone with black shale intercalation

$\square$ covered section

- taxon left in open nomenclature

taxa ranges according to

Klapper (1977) and Klapper et al. (1979)

- taxa ranges according to Zusková (1991)

* estimated thickness of covered, unaccesible section 5 m

Figure 2. A - simplified lithological column of the Prastav quarry with conodont ranges. The bases of the serotinus and patulus zones are drawn according to data published by Klapper (1977a) (the lower part of the section was not sampled). $\bullet$ B - simplified lithological column of the Barrandov road cut section with conodont ranges. The bases of the patulus and partitus zones were drawn according to data published by Zusková (1991). Abbreviations: pa. - patulus Zone, au. - australis Zone, kockel. - kockelianus Zone.

(see text below) which was found $0.2 \mathrm{~m}$ above the base of the Choteč Limestone. According to previously compiled data (Weddige 1977, Klapper \& Johnson 1980, Wang \& Ziegler 1983, Bardashev 1992), the earliest occurrence of $P$. trigonicus is known from the australis Zone. Similarly, the lower stratigraphical range of P. pseudofoliatus was recorded in the australis Zone (Weddige 1977, Klapper \& Johnson 1980, Wang \& Ziegler 1983, Mawson \& Talent 1989, Bardashev 1992) with the exception of its occurrence in the costatus Zone as recorded by Belka et al. (1997). Therefore, in this locality, the base of the australis Zone was drawn (with the question mark) on the basis of the occurrences of P. pseudofoliatus and $P$. trigonicus.
$\mathrm{Na}$ vyhlídce at Hostím, Fig. $4 A$ (49 $57^{\prime} 41,9^{\prime \prime} \mathrm{N}$, $14^{\circ} 07^{\prime} 48^{\prime \prime} E$ ). - Exposures of the Třebotov Limestone and almost the whole succession of the Choteč Limestone occur in small, abandoned quarries and in the cutting of the path on the left bank of the Loděnice ("Kačák") brook. Close surroundings were studied by Svoboda \& Prantl (1953), Chlupáč (1959) and Chlupáč et al. (1979). Conodont faunas are scarce in this section, thus more sampling associated with trenching (parts of the section are covered) is necessary. The following conodont zones have been recorded so far: serotinus, partitus, costatus and kockelianus zones, the base of the australis Zone is questioned here as it is drawn according to the occurrence of $P$. pseudofoliatus. However, as mentioned above, the occurrence 


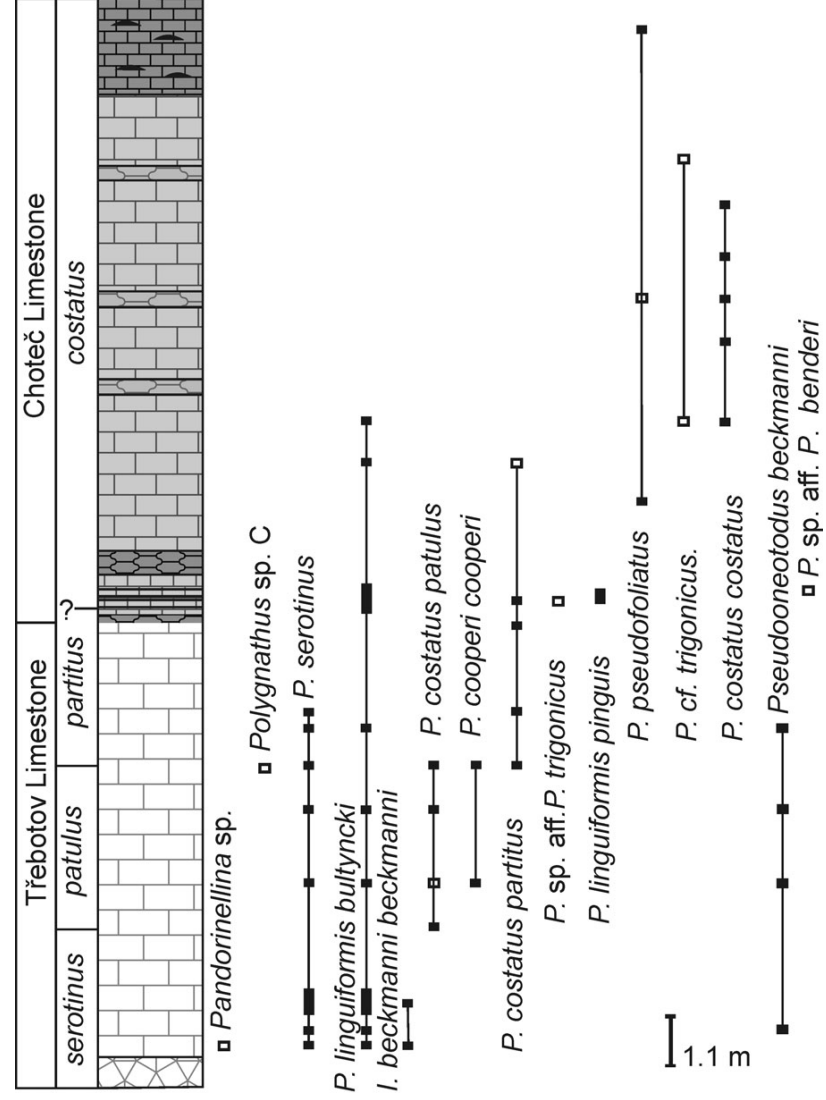

Figure 3. Simplified lithological column of the Na Škrábku quarry at Choteč with conodont ranges. See legend in Fig. 2. The base of the costatus Zone is drawn according to the occurrence of $P$. sp. aff. P. trigonicus.

of P. pseudofoliatus in the costatus Zone as recorded by Belka et al. (1997), should be taken into account.

Jelinek mill at Chýnice, Fig. 4B (4959'50,6" $\mathrm{N}$, $\left.14^{\circ} 16^{\prime} 13,8^{\prime \prime} \mathrm{E}\right)$. - An old quarry situated on the left bank of the Radotínský potok brook, E of the Chýnice village. Almost the whole succession of the Třebotov and Choteč limestones crop out here. This section was studied in detail by Chlupáč (1959), Klapper (1977), Klapper et al. (1978) and Chlupáč et al. (1979). Klapper (1977) provided the first conodont data from this section, recording patulus, partitus and costatus zones. The following zones have been recorded in this study: serotinus, patulus, partitus, costatus, australis and kockelianus zones. The first $P$. c. patulus was recorded $5.6 \mathrm{~m}$ below the base of the Choteč Limestone, the first $P$. c. partitus was recorded $4.7 \mathrm{~m}$ below that same datum, thus the thickness of rock corresponding to the patulus Zone would be approximately $1 \mathrm{~m}$, which is comparable to the Prastav quarry, where it is even less $-0.5 \mathrm{~m}$ and the Barrandov road cut, where it is $1.8 \mathrm{~m}$. However, more detailed sampling should be carried out to confirm this, as taphonomic and sampling biases cannot be ruled out. The first $P$. c. costatus was found
$0.9 \mathrm{~m}$ above the base of the Choteč Limestone, which is in agreement with Klapper (1977), who recorded this taxon from the interval of $1.03-1.13 \mathrm{~m}$ above the base, together with Polygnathus sp. aff. P. trigonicus. This fact supports the possibility of a correlation between the last mentioned taxon with the base of the costatus Zone in the Prague Basin. Polygnathus sp. aff. P. trigonicus was recorded in this study $6 \mathrm{~m}$ above the base of the Choteč Limestone $(5 \mathrm{~m}$ above FAD of P. c. costatus). The first appearance of Tortodus kockelianus australis was recorded approximately $30 \mathrm{~m}$ above the base of the Choteč Limestone in this study; an exact measurement cannot be given, as parts of the section are covered and inaccessible. The first $T . k$. kockelianus was found $3 \mathrm{~m}$ above the first appearance of T. k. australis.

U Němců section at Karlštejn (N 49 ${ }^{\circ} 56^{\prime}$ 37.207", E 14 $11^{\prime}$ 0. 96"). - The whole succession of the Třebotov and Choteč limestones are exposed in this section in Karlštejn village, in the backyard (and surroundings) of a private house, opposite to the small hotel "Pod Dračí skálou". Svoboda \& Prantl (1955), Chlupáč (1959), and Budil (1995) studied the immediate surroundings. The conodont fauna is very scarce here, especially in the Choteč Limestone. P. serotinus, $P$. linguiformis bultyncki, P. c. partitus, $P$. c. costatus and unidentifiable juveniles only were found. $P$. c. partitus was found $3 \mathrm{~m}$ below the base of the Chotec Limestone, represented by only one specimen. One specimen of $P$. c. costatus was found 10 meters above the base of the Choteč Limestone. This outcrop represents a very important section, with the whole succession of the Třebotov Limestone (graded from the Daleje shales) and the Choteč Limestone (overlain by the Srbsko Formation) being exposed and therefore the present author continues to seek more data and to construct a more precise conodont zonal scheme for this section.

Červený quarry near Suchomasty (49 54'37.54" N, $14^{\circ} 04^{\prime} 38.35^{\prime \prime} E$ ). - A quarry situated SE of the Koněprusy village, near the road from Koněprusy to Suchomasty, the stratotype of the Suchomasty Limestone. The whole succession of the Suchomasty Limestone and the base of the Acanthopyge Limestone are exposed. The following authors considered the stratigraphy, paleontology and sedimentology of this section: Chlupáč (1959), Chlupáč et al. (1979), Klapper (1977), Klapper et al. (1978), Weddige \& Ziegler (1987), Havlíček \& Kukal (1990), Galle \& Hladil (1991), Ellwood et al. (2006) and Koptíková (accepted). Conodont biostratigraphy of the Suchomasty Limestone was provided in detail by Klapper (1977), Klapper \& Zikmundová in Chlupáč et al. (1977) and Klapper et al. (1978). The cited authors recorded the following conodont zones: laticostatus, serotinus, patulus and partitus zones. Only the very base of the Acanthopyge Limestone was for- 
A

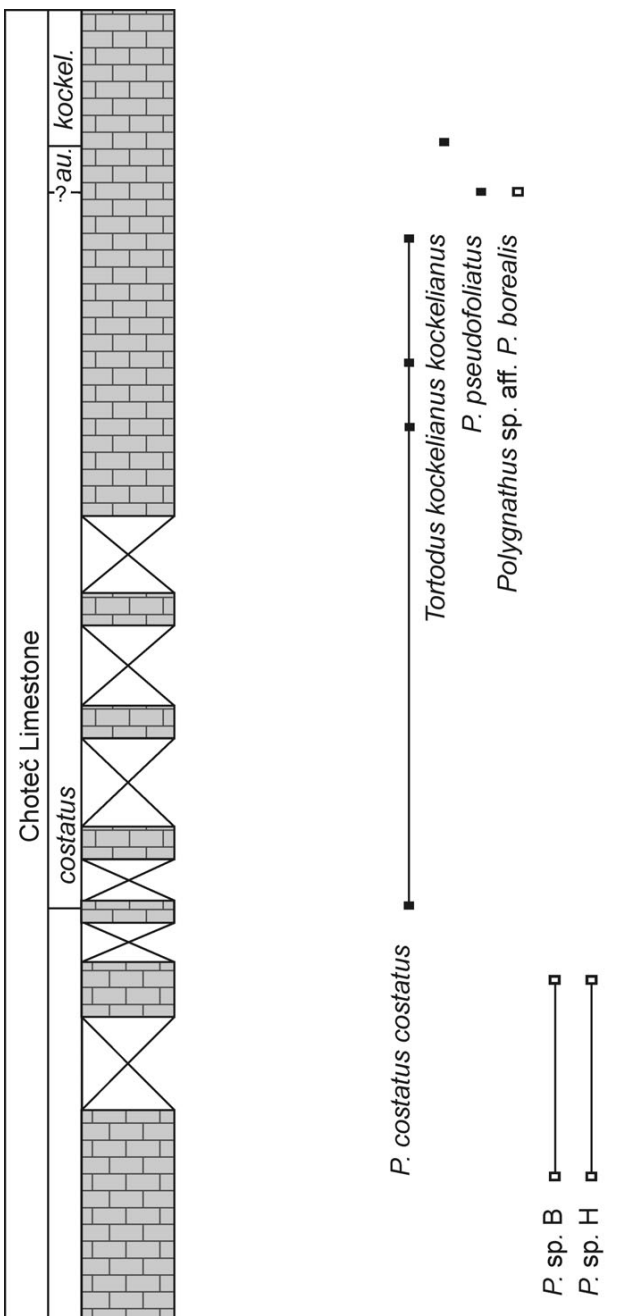

B

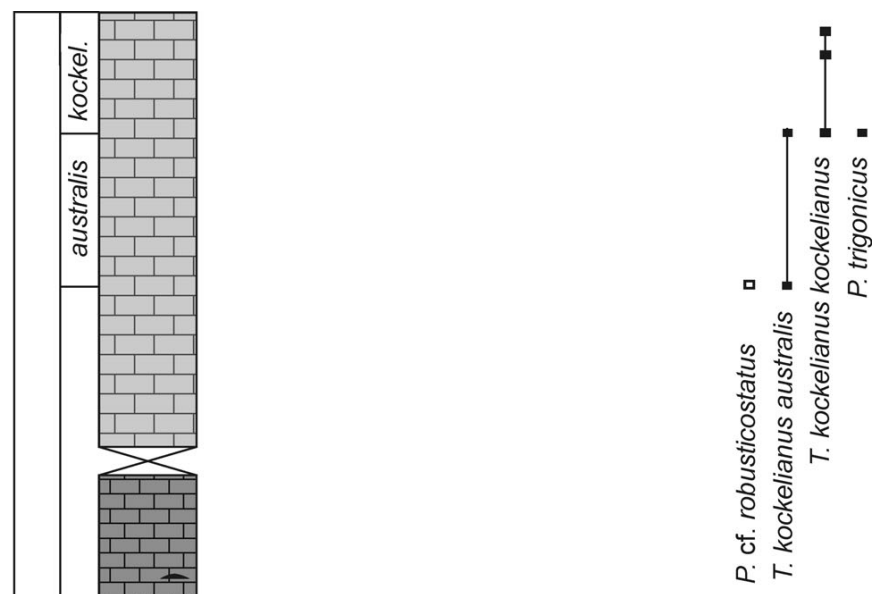

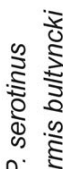
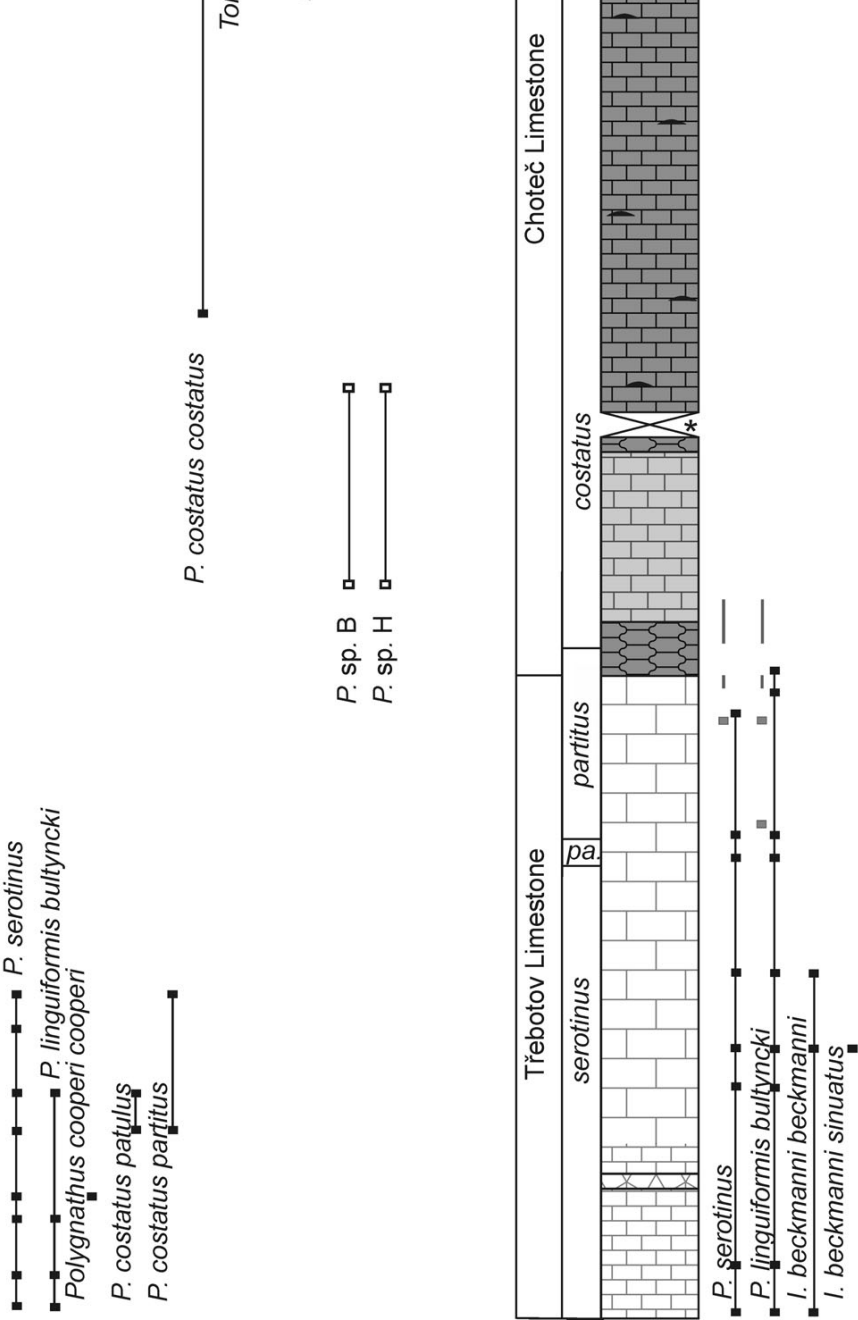

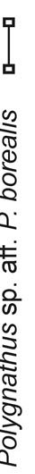

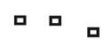

$\leftarrow 0-$

के के के

$\stackrel{2}{2} \stackrel{5}{3}$

苑

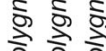

०० एव

Figure 4. Simplified lithological columns of the Na vyhlídce section at Hostím (A) and Jelínek mill quarry at Chýnice (B) with conodont ranges. See legend in Fig. 2.

merly accessible at this quarry and thus this unit has not been sampled, except for its base, where Klapper et al. (1978) recorded $P$. sp. aff. $P$. trigonicus, $P$. c. partitus and P. l. bultyncki. Conodonts are more common in both the Suchomasty and Acanthopyge limestones in comparison to ot- her studied sections; furthermore, adult specimens are better represented here. The occurrence of $P$. serotinus in the Acanthopyge Limestone was recorded, which is in contrast to other sections in the Prague Basin where elements of this taxon were not recorded from the Choteč Limestone. 


\section{Correlation of the costatus Zone, occurrence of Polygnathus sp. aff. $P$. trigonicus and the base of the Choteč Limestone}

As mentioned previously, the onset of sedimentation of the Choteč Limestone reflected the effects of the Basal Choteč event, which has been roughly correlated with the base of the costatus Zone (Chlupáč \& Kukal 1986). The appearance of $P$. c. costatus in this study was recorded at $1 \mathrm{~m}$ above the base of the Choteč Limestone in the Jelinek mill section, $5 \mathrm{~m}$ above the base of the Choteč Limestone in Na Škrábku quarry and $2 \mathrm{~m}$ above its base in the Prastav quarry. The exception is its occurrence at the Barrandov road-cut section, where its FAD was recorded $1.25 \mathrm{~m}$ below the base of the Choteč Limestone (below the first dark crinoidal grainstone). With respect to this, it is necessary to mention that a change in sedimentation had already been observed at the top of the Třebotov Limestone in this section, approximately at the level of the FAD of P. c. costatus. The sediments at this level are represented by skeletal wacke-packstones with intercalation of organic rich, bioturbated wackestone with prasinophytes (green algae). Similar algal blooms are also found at the base of the Choteč Limestone elsewhere in the Prague Basin (e.g. Na Škrábku quarry, U Němců section and also, to a lesser extent, Prastav quarry). The level with prasinophyte accumulation in this section is regarded as a first lithological manifestation of environmental changes that took place (the Basal Choteč event), therefore, it seems so far that the supposed correlation of the above mentioned event with the base of the costatus Zone can be supported.

The correlation of the base of the Choteč Limestone with the base of the costatus Zone (defined by the first appearance of $P$. c. costatus) may not be exactly coincident. As mentioned above, the base of the Choteč Limestone is in most sections represented by graded grainstones, the sedimentation of which may have been very fast. Furthermore, the rate and pattern of sedimentation may have been different in individual sections; therefore the first appearance of this taxon may have been affected by those circumstances. According to both new and previously published data (Klapper, personal communication, Klapper et al. 1978), it seems that the occurrence of Polygnathus sp. aff. P. trigonicus is characteristic for the base of the costatus Zone, not only in the Prague Basin but also elsewhere (Klapper 1971, Perry et al. 1974). For the above-mentioned reason, the base of the costatus Zone in the $\mathrm{Na}$ Škrábku quarry section is drawn according to the FAD of this taxon. Klapper at al. (1978) described Polygnathus sp. aff. $P$. trigonicus $1.75-1.8 \mathrm{~m}$ above the base of Chotec Limestone in the Prastav quarry, which is $20 \mathrm{~cm}$ below the FAD of $P$. c. costatus (this study). Similarly, in this study this taxon was found $30 \mathrm{~cm}$ above the base of the Chotec
Limestone at the Barrandov road-cut section (1.6 m above the bed with the first $P$. c. costatus). Klapper et al. (1978) also recorded $P$. sp. aff. $P$. trigonicus and $P$. c c costatus from the same sample approximately $1 \mathrm{~m}$ above the base of the Choteč Limestone in the Jelínek mill quarry. If this correlation proves to be valid, then it would have important implications for global correlation of the costatus Zone and consequently, the Basal Choteč event.

\section{Conodont biostratigraphy}

It should be remembered that the Lower-Middle Devonian conodont zonal concept does not mirror the total ranges of the zonally defining taxa. The persistence of a stratigraphically older taxon into a younger zone or zones is common. The principle of using a first appearance datum of a zonal taxon to define the base of a particular zone was followed (Weddige 1977, Weddige et al. 1979, Klapper 1977a). With the exception of $P$. serotinus, $T$. kockelianus kockelianus and T. $k$. australis the zonal scheme is based on the $P$. costatus patulus, $P$. c. partitus and $P$. c. costatus lineage, thus on taxa with close phylogenetic affinity. Because of that, certain problems in global correlations may arise as a consequence of different taxonomical approaches. Therefore, significant attention was paid in this paper to the description and photographic illustration of the "costatus group" from the Prague Basin, which represents the type area of one of the zonally defining subspecies (P. c. parti$t u s)$. The conodont faunas studied are of very low diversity and also abundance, spanning six zones (serotinus-kockelianus zones). Representatives of juveniles in the offshore deposits prevail, which complicated the taxonomic and biostratigraphic assessment to a certain point, as juveniles cannot be identified to the species level with confidence. On the other hand, in the more shallow water settings (Červený quarry, Koněprusy area) adults prevail.

The ranges of zonally defining taxa found in the Prague Basin were as follows: $P$. serotinus (index taxon of the serotinus Zone) was recorded in the serotinus, patulus, partitus zones and at the very base of the costatus Zone (the last $P$. serotinus was found in the sample with the first $P$. $c$. costatus). P. costatus patulus (index taxon of the patulus Zone) was recorded in the patulus, partitus and the base of the costatus zones. $P$. c. partitus (index taxon of the partitus Zone) was recorded in the partitus and costatus zones. $P$. c. costatus (index taxon of the costatus Zone) was recorded in the costatus and australis zones. Representatives of T. k. australis (index taxon of the australis Zone) were not found in sufficient numbers to make a judgment about its stratigraphical range. Only two specimens were found, not however in the sample with $T$. k. kockelianus (index taxon for the kockelianus Zone). Only rocks corresponding to the base of the kockelianus Zone (upper part of the 
Choteč Limestone) were sampled and thus the stratigraphical range of the last taxon cannot be discussed. The abovementioned findings are in agreement with data published by Klapper et al. (1978) from the Prague Basin (with the exception that a higher range of $P$. c. costatus was recorded in this study) and also with data from Europe (e.g., Ziegler 1977), N. Africa (e.g., Belka et al. 1999), N. America (e.g., Klapper \& Johnson 1980), Australia (e.g., Mawson \& Talent 1989) and Asia (e.g., Wang \& Ziegler 1983). For discussion of the upper range of $P$. serotinus see below. On the basis of the authors's own observations and data already published, is seems so far, that only the australis Zone is defined by the total range of its defining taxon (but see also Klapper \& Johnson 1980, p. 422, table 8 for recorded occurrence of $T . k$. australis in the kockelianus Zone in the Rhenish Slate Mts). Upper ranges of zonally defining taxa, which extend into a younger zone (zones), may represent a handicap for correlation, especially when only a limited number of elements are recovered. Therefore, the conodont zonation itself may not be a perfect correlation tool for this critical time interval (serotinus-kockelianus zones). If possible, the accompanying fauna should be taken into consideration, not only conodont taxa but also other fossil groups (e.g., dacryoconarid tentaculites). In addition, the usage of other stratigraphical methods such as chemostratigraphy and magnetic susceptibility is very promising for regional as well as global correlations.

The following genera and species were recovered: Polygnathus serotinus, P. linguiformis bultyncki, Icriodus beckmanni beckmanni, I. b. sinuatus, Ozarkodina carinthiaca, P. cooperi cooperi, P. costatus patulus, P. c. partitus, $P$. costatus costatus, $P$. sp. aff. $P$. trigonicus, $P$. linguiformis pinguis, $P$. trigonicus, Tortodus kockelianus australis, T. $k$. kockelianus, P. pseudofoliatus, Pelekysgnathus sp., Pandorinellina sp., Pseudooneotodus beckmanni, $P$. sp. aff. $P$. borealis and several new species, which are not discussed in this paper. For conodont taxa ranges from selected sections, see Figs 2-4. All above mentioned taxa, except $P$. sp. aff. $P$. borealis and Pandorinellina sp., are figured in Figs 5-10.

Serotinus Zone (Třebotov Limestone). - Weddige (1977) defined the lower boundary on the first appearance of Polygnathus serotinus and the upper boundary on the first appearance of $P$. c. patulus. Apart from $P$. serotinus, this zone marks the lowest appearance of $P$. l. bultynkci (together with $P$. serotinus being the most common taxa in the Třebotov Limestone, very often the only constituents). Other taxa occurring within this zone are: Ozarkodina carinthiaca (rare), Pandorinellina sp. (rare), Pseudooneotodus beckmanni (very abundant), Icriodus beckmanni beckmanni and I. $b$. sinuatus (not abundant).

Patulus Zone (Třebotov Limestone). - Weddige (1977) defined the lower boundary on the first occurrence of $P$. c. pa- tulus and the upper boundary by the appearance of $P$. $c$. partitus, (P. c. costatus in the original definition). P. c. patulus represents a rather rare taxon, most commonly found in the upper part of the Třebotov Limestone, together with $P$. c. partitus, thus already in the partitus Zone. Therefore, the base of the patulus Zone in the Prastav quarry and in the Barrandov road cut must be drawn according to previously published data by Klapper et al. (1978) and Zusková (1991). Other taxa present in this zone are: P. c. cooperi (rare), $P$. serotinus (very abundant), $P$. l. bultyncki (very abundant) and Pseudooneotodus beckmanni (abundant).

Partitus Zone (upper part of the Třebotov Limestone-lowermost Choteč Limestone). - Weddige at al. (1979) suggested this as a new name for the upper patulus Zone of Klapper et al. (1978). The base of this zone defines the Lower-Middle Devonian boundary. The lowermost occurrence of P. c. partitus was recorded $5 \mathrm{~m}$ below the top of the Trrebotov Limestone in the Prastav quarry. This section represents the regional reference section for the Lower-Middle Devonian boundary; the previously published FAD of this taxon was at the level of $2.8 \mathrm{~m}$ below the top of the Třebotov Limestone (Klapper et al. 1978, Chlupáč et al. 1979). Other taxa occurring within this Zone are: $P$. serotinus (very abundant), $P$. $l$. bultyncki (very abundant) and P. c. patulus (rare).

Costatus Zone (uppermost part of the Třbotov Limestone and the majority of the Choteč Limestone). - Weddige (1977) defined the lower boundary of the zone on the first appearance of $P$. c. costatus and the upper boundary on the lowest appearance of Tortodus kockelianus australis (T. $k$. kockelianus in the original definition). The base of this zone roughly coincides with the main lithologic and faunistic changes, known as the Basal Choteč event which occured in the Prague Basin and elsewhere (see Chlupáč \& Kukal 1988 for additional references). The disappearance of $P$. serotinus from this area is characteristic for this time interval as no element of $P$. serotinus has been found in the Choteč Limestone within this study. The occurrence of $P$. serotinus together with $P$. c. costatus was recorded $1.25 \mathrm{~m}$ below the base of the Choteč Limestone in the Barrandov section. This finding represents the only record of $P$. serotinus in the costatus Zone in the Prague Basin within this study. According to Klapper (1977), Klapper et al. (1978) and Klapper (2009, personal communication), the last $P$. serotinus in the Prague Basin was found together with P. c. costatus from $2.28-2.33 \mathrm{~m}$ above the base of the Choteč Limestone in the Jelínek mill quarry. Thus, in contrast to other regions, where P. serotinus is common in the costatus Zone (e.g., Klapper 1977b, Bardashev 1992), in the Prague Basin the occurrence of $P$. serotinus is limited just to the very base of the costatus Zone (the last specimen of $P$. serotinus was found together with first $P$. c. costatus). The occurrence of Polygnathus sp. aff. P. trigonicus seems to be 
characteristic for the base of this zone. Other taxa within this zone comprise $P$. c. patulus (rare), $P$. c . partitus (relatively common in the lower part), $P$. linguiformis bultyncki (abundant), P. l. pinguis (rare) and Pelekysgnathus sp. (rare).

Australis Zone (upper part of the Choteč Limestone). This zone was designated by Philip \& Jackson (1973) as an assemblage and re-defined by Klapper (1977a) as a zone, the base of which coincides with the first appearance of $T$. k. australis, corresponding to the base of the kockelianus Zone sensu Weddige (1977). In this study, the base of this zone was drawn on the basis of the occurrence of two specimens in the Jelínek mill section. The australis Zone was identified also in the Barrandov road cut and in the $\mathrm{Na}$ Škrábku quarry, with a question on the basis of the presence of $P$. pseudofoliatus (Barrandov road cut) and $P$. pseudofoliatus and $P$. trigonicus (Na Škrábku quarry). For an explanation see the text above.

Kockelianus Zone. - Weddige (1977) defined the lower boundary of the zone on the first appearance of T. k. kockelianus and the upper boundary on the appearance of Polygnathus xylus ensensis. In this study the kockelianus Zone was identified only in the upper part of the Choteč Limestone in the Jelínek mill quarry in grey bioturbated wackestones. Also in the section situated on the road between Hostím and Srbsko villages, within the interval with tempestite sedimentation and in the $\mathrm{Na}$ vyhlídce section in Hostím within dark-grey lime mudstones and wackestones with silicites.

\section{Conclusions}

Conodonts from the Trrebotov Limestone (EmsianEifelian) and the Choteč Limestone (Eifelian) of the Prague Basin were studied. Seven sections were sampled in order to refine the existing conodont zonal scheme and to provide new data for sections that have not been included in previous studies. The most important findings can be summarized as follows:

1. The zonal scheme was re-defined in the Jelínek mill quarry, where boundaries of the partitus and patulus zones are lower than in previous studies (Klapper et al. 1978); also the australis and kockelianus zones were newly recorded here. Furthermore, new data on the lower and/or upper ranges of other taxa were determined.

2. The supposed correlation of the Basal Choteč event with the base of the costatus Zone is supported. First representatives of $P$. c. costatus are, with the exception of Barrandov road cut section, always found at the base of the Choteč Limestone (the sedimentation of this unit reflects changes linked to the above mentioned event). In the Barrandov road cut, the base of the costatus Zone was recorded $1.25 \mathrm{~m}$ below the base of the Choteč Limestone, which represents the first find of this taxon below the base of this unit. However, changes in sedimentation at this section (linked to the Basal Choteč event) have already been observed at this level (prasinophyte blooms recorded about $1 \mathrm{~m}$ below the base of the Choteč Limestone).

3. At the regional reference section for the Lower-Middle Devonian boundary, the Prastav quarry at Holyně, the first occurrence of $P$. c. partitus was recorded $5 \mathrm{~m}$ below the base of the Choteč Limestone. Thus the Lower-Middle Devonian boundary, which is drawn according to first occurrence of this taxon, is shifted $2.3 \mathrm{~m}$ lower. In addition, the costatus Zone was identified here on the basis of the nominal species for the first time, $2 \mathrm{~m}$ above the base of the Choteč Limestone.

4. The disappearance of Polygnathus serotinus at the very base of the costatus Zone from this area has been recorded. This taxon represents the most common species in the Třebotov Limestone; no single element of this taxon was found in the overlying unit, namely, the Choteč Limestone, in this study. This is in contrast with other regions, where it is quite common in the costatus Zone (e.g., Klapper 1977b, Bardashev 1992).

5. According to new data and previously published data (Klapper 1977a, Klapper et al. 1978) it appears possible to correlate the occurrence of Polygnathus sp. aff. $P$. trigonicus with the lower part of the costatus Zone in the Prague Basin, as elsewhere (Klapper 1971, Perry et al. 1974). Both that species and P. c. costatus occur close to the base of the Choteč Limestone, which reflects the effect of the Basal Choteč event. Therefore, the occurrence of $P$. sp. aff. P. trigonicus may also have implications for global correlation of this event.

6. Based on data already published and also on the author's own observations on ranges of zonally defining taxa, the conclusion has been reached that global, as well as regional, correlations of the studied interval (serotinuskockelianus zones) should not be, at best, based only on conodont zonation. Other fossils groups and also other stratigraphical methods (e.g., chemostratigraphy, magnetic susceptibility) should be considered.

\section{Systematic section}

Conodont elements were extracted using standard techniques, which comprise dissolution of limestones in $6 \%$ acetic acid, sieving and drying the residues and handpicking the elements using a Carl Zeiss binocular microscope (magnification of 16-40x). Separation in a heavy liquid (sodium polytungstate) was carried out. SEM documentation was made at the Institute of Geology and Paleontology, Charles University, Prague, using the JEOL JSM-6380. Specimens studied are deposited in the collection of Stanislava Berkyová, at the Czech Geological Survey (SB2). 


\section{Genus Polygnathus Hinde, 1879}

Type species. - Polygnathus dubius Hinde, 1879.

\section{Polygnathus costatus Klapper, 1971}

\section{Polygnathus costatus patulus Klapper, 1971} Figure $5 \mathrm{~A}-\mathrm{C}$

1971 Polygnathus costatus patulus subsp. nov.; Klapper, pp. 62 , 63, pl. 1, figs $1-9,29$; pl. 3, figs 16-18.

1977 Polygnathus costatus patulus Klapper 1971. - Weddige, pp. 310, 311, pl. 4, fig. 74.

1978 Polygnathus costatus patulus Klapper, 1971. - Klapper et al., pl. 2, figs 6-9, 14-17, 19, 20, 25, 31.

1980 Polygnathus costatus patulus Klapper. - Johnson et al., pl. 4, fig. 13.

1983 Polygnathus costatus patulus Klapper, 1971. - Wang \& Ziegler, pl. 5, figs 11-14.

1984 Polygnathus costatus patulus Klapper. - Feist et al., pl. 1, fig. ?8, pl. 2, fig. ?18, ?19, 21, ?22.

1986 Polygnathus costatus patulus Klapper, 1971. - Bultynck, p. 270, pl. 8, figs 1-6.

1986 Polygnathus costatus patulus Klapper. - Schönlaub, pl. 4, figs 4, 5, 8, ?6, ?7.

1986 Polygnathus costatus patulus Klapper, 1971. - Ziegler \& Wang, pl. 1, figs 11, 12,?13.

1986 Polygnathus costatus patulus Klapper. - Bardashev \& Ziegler, pl. 1, fig. 1.

non 1989 Polygnathus costatus patulus Klapper. - Mawson \& Talent, pl. 3, fig. 3 [P. linguiformis bultynkci].

1992 Polygnathus costatus patulus Klapper, 1971. - Bardashev, pl. 1, fig. 11.

1992 Polygnathus costatus patulus Klapper, 1971. - Bardashev \& Ziegler, pl. 6, figs 33-34.

1992 Polygnathus costatus patulus Klapper, 1971. - Boncheva, p. 36, pl. 2, figs ?4-8 (only lower views).

1994 Polygnathus costatus patulus Klapper. - Mawson \& Talent, pl. 2, fig. 1.

1995 Polygnathus costatus patulus Klapper, 1971. - Mawson et al., pp. 430-431, pl. 3, fig. 8.

2003 Polygnathus costatus patulus Klapper, 1971. - Benfrika \& Bultynck, pl. 1, fig. 9.

Material. - 42 specimens.

Description. - Pa elements of $P$. c. patulus from the Prague Basin have an almost symmetrical (outer platform is slightly wider), broad platform. The anterior platform margins are slightly constricted. Upper view: the carina reaches the posterior end of the platform, at least in the form of nodes. Adcarinal grooves are relatively deep, mainly in the anterior part of the platform and wide-forming the characteristic shape of the platform, which is widest at about its midlength. The platform of the Pa element bears short, but prominent transverse ridges (16-20 ridges on both sides of platform in mature specimens). Lower view: the centre of the small pit is situated at the border between the first and second quarter of the platform (in the anterior part of platform). The keel is straight or only slightly curved.

Remarks. - P. c. patulus is similar to $P$. c. partitus as they share some diagnostic features though they are distinguishable on the basis of the platform outline. However, this applies only to adult specimens. The platform of P. c. patulus is widest at about its midlength whereas the platform of $P$. c. partitus is narrow, and its anterior margins are almost parallel. P. c. patulus also resembles $P$. cooperi cooperi Klapper, 1971 (serotinus-patulus zones). The latter differs by the more asymmetrical development of the platform and especially by the development of a weak tongue, which usually bears two transverse ridges.

Stratigraphical range. - Late Emsian to early Eifelian (Lower-Middle Devonian), the first occurrence of this taxon defines the lower boundary of the patulus Zone. In the Prague Basin, the lowest occurrence is $7.3 \mathrm{~m}$ below the base of the Choteč Limestone in Na Škrábku quarry, the highest occurrence is $2.38 \mathrm{~m}$ above the base of the Choteč Limestone in the Jelínek mill section (the lower part of the costatus Zone).

\section{Polygnathus costatus partitus Klapper, Ziegler \& Mashkova, 1978 \\ Figure 5D-I}

1978 Polygnathus costatus partitus subsp. nov.; Klapper et al., p. 109, pl. 2, figs 1-5, 13.

1983 Polygnathus costatus partitus Klapper, Ziegler \& Mashkova, 1978. - Wang \& Ziegler, pl. 5, fig. 12.

1986 Polygnathus c. partitus Klapper, Ziegler \& Mashkova. - Bardashev \& Ziegler, pl. 1, figs 2,?3.

1986 Polygnathus costatus partitus Klapper, Ziegler \& Mashkova, 1978. - Bultynck, p. 270, pl. 8, figs 19, 20.

1986 Polygnathus costatus partitus Klapper, Ziegler \& Mashkova. - Schönlaub, pl. 4, figs 9, 10.

1986 Polygnathus costatus costatus Klapper. - Schönlaub, pl. 4, fig. 11.

1986 Polygnathus costatus partitus Klapper, Ziegler \& Mashkova, 1978. - Ziegler \& Wang, pl. 1, fig. 14.

1989 Polygnathus costatus partitus Klapper, Ziegler \& Mashkova. - Mawson \& Talent, pl. 3, fig. 4.

1992 Polygnathus costatus partitus Klapper, Ziegler \& Mashkova, 1978. - Bardashev, pl. 1, figs 14-17, 21-22, ?18-20.

1992 Polygnathus costatus partitus Klapper, Ziegler \& Mashkova, 1978. - Boncheva, p. 36, pl. 2, figs ?2,?3 [non fig. 1]. 
1994 Polygnathus costatus partitus Klapper, Ziegler \& Mashkova. - Mawson \& Talent, pl. 2, figs 2,?3.

1995 Polygnathus costatus partitus Klapper, Ziegler \& Mashkova, 1978. - Sloan et al., pl. 5, figs 15-19.

Material. - 74 specimens.

Description. - Pa elements of $P$. c. partitus from the Prague Basin have an almost symmetrical (outer platform is slightly wider), narrow platform, where the inner and outer posterior platform margins tend to be straight, meeting the posterior end of the platform to form a "sagittate" outline. The anterior platform margins are either parallel or only slightly constricted. Upper view: the carina reaches the posterior end of the platform, at least in the form of nodes. The platform of the $\mathrm{Pa}$ element bears short but prominent transverse ridges (16-20 ridges on both sides of the platform in mature specimens). Adcarinal grooves are relatively deep in the anterior part of the platform. Lower view: the centre of the small pit is situated on the border between the first and second quarter of the platform (in the anterior part of the platform). The keel is straight or only slightly curved.

Remarks. - Polygnathus c. partitus was described by Klapper et al. (1978) as a phyletic intermediate between $P$. $c$. patulus and $P$. c. costatus from which it can be distinguished essentially by the development of the platform margins, which are characteristically straight and by the narrow platform development. A comparison of all subspecies is given in the section on P. c. costatus.

Stratigraphical range. - Eifelian (early Middle Devonian), first occurrence of this taxon defines the lower boundary of the partitus Zone. In the Prague Basin, the first occurrence of this taxon falls in the upper part of the Třebotov Limestone. The lowest occurrence found is $5 \mathrm{~m}$ below the top of the Třebotov Limestone in the Prastav quarry (this study). The highest occurrence is $2.46 \mathrm{~m}$ above the base of the Choteč Limestone in the Barrandov road-cut (this study, lower part of the costatus Zone).

\section{Polygnathus costatus costatus Klapper, 1971 Figure 6I-L}

1971 Polygnathus costatus costatus subsp. nov.; Klapper, p. 64, pl. 1, figs 30-36, pl. 2, figs 1-7.
1974 Polygnathus costatus costatus Klapper 1971. - Perry et al., p. 1087, pl. 7, figs 1, ?2, 3, 4, 5, ?6, ?7, ?10.

1977 Polygnathus costatus costatus Klapper 1971. - Weddige, pp. 309, 310, pl. 4, figs 75-76.

1978 Polygnathus costatus costatus Klapper, 1971. Klapper et al., pl. 2, figs ?10, ?11, 12.

1980 Polygnathus costatus costatus Klapper. - Johnson et al., pl. 4, figs 14, 15, 17.

1983 Polygnathus costatus costatus Klapper, 1971. - Sparling, pl. 10, figs $\mathrm{AB}, \mathrm{AC}$; pl. 11, figs $\mathrm{AB}, \mathrm{AC}, \mathrm{AF}, \mathrm{AG}$.

1985 Polygnathus costatus costatus Klapper. - Feist et al., pl. 1, figs 2, ?3, ?4, 5, ?9., pl. 2, figs ?24, ?25, ?27, ?28.

1986 Polygnathus costatus costatus Klapper. - Bardashev \& Ziegler, pl. 1, figs 4, 5 .

1986 Polygnathus costatus costatus Klapper, 1971. - Bultynck, p. 270, pl. 8, figs 13-17.

1986 Polygnathus costatus costatus Klapper. - Schönlaub, pl. 4, figs 12-15 [non fig. $11=P$. costatus partitus]

1986 Polygnathus costatus costatus Klapper, 1971. - Ziegler \& Wang, pl. 1, figs 17-19.

?1989 Polygnathus costatus costatus Klapper. - Mawson \& Talent, pl. 3, fig. 5.

non 1990 Polygnathus costatus costatus Klapper, 1971. - Lazreq, pl. 1, fig. 10.

1992 Polygnathus costatus costatus Klapper, 1971. - Bardashev, pl. 1, figs 23-31.

1994 Polygnathus costatus costatus Klapper. - Mawson \& Talent, pl. 2, figs 9-12.

1995 Polygnathus costatus costatus Klapper, 1971. - Savage, p. 545 , pl. 8 , fig. 3 .

1995 Polygnathus costatus costatus Klapper, 1971. Sloan et al., pl. 6, figs 1-6.

2003 Polygnathus costatus costatus Klapper, 1971. - Benfrika \& Bultynck, pl. 1, fig. 10

2003 Polygnathus costatus costatus Klapper, 1971. - Pyle et al., pl. 2, figs 1-2.

Material. - 53 specimens.

Description. - Pa elements of P. c. costatus from the Prague Basin have an almost symmetrical (outer platform is slightly wider), long, narrow platform. The anterior platform margins are slightly constricted. Upper view: the adcarinal grooves are relatively deep and narrow in the anterior part of platform. In the last third of the platform, grooves tend to be wider, thus forming the characteristic shape of the platform, which is

Figure 5. A-D - upper and lower views of Polygnathus costatus patulus Klapper, 1971. A - Na Škrábku quarry, 7.3 m below the base of the Choteč Limestone. B, D - Červený quarry, $2.3 \mathrm{~m}$ above the base of the Acanthopyge Limestone. C - Červený quarry, $0.35 \mathrm{~m}$ above the base of the Acanthopyge Limestone. • E-I - upper and lower views of Polygnathus costatus partitus Klapper, Ziegler \& Mashkova, 1978. E - Červený quarry, 0.35 m above the base of the Acanthopyge Limestone. F-H - Červený quarry, $2.3 \mathrm{~m}$ above the base of the Acanthopyge Limestone. I - Barrandov road cut, $0.7 \mathrm{~m}$ below the Choteč Limestone. All magnifications are $\times 60$. 


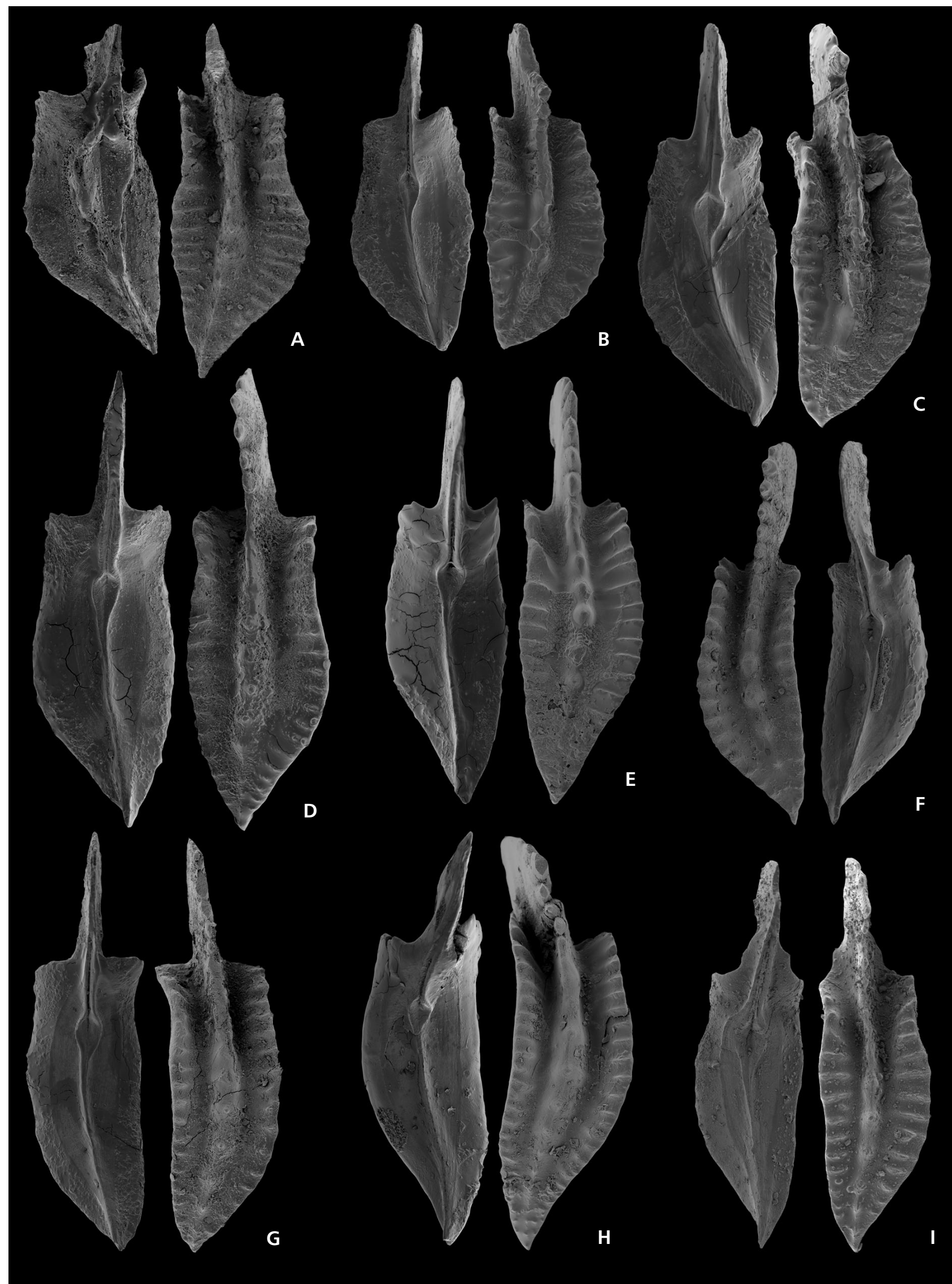


widest in its final third (in the posterior part). The carina reaches the posterior end of the platform. The platform of the $\mathrm{Pa}$ element bears prominent, densely spaced transverse ridges (25-30 ridges on both sides of the platform in adult specimens). Lower view: the centre of the small pit is situated on the boundary between the first and second third of the platform. The keel may or may not be slightly curved.

Remarks. - P. c. costatus is easily distinguishable from $P$. c. patulus and $P$. c. partitus by its long, narrow platform, which is widest in the posterior third of the platform. The platform is longer and bears more densely spaced transverse ridges in comparison with the other two subspecies. The platform outline is regarded here as the most important diagnostic feature. The platform of $P$. c. patulus is broad and widest at midlenght, the platform of $P$. c. partitus is narrow and the anterior margins of the platform are more or less parallel, the platform of $P$. c. costatus is long, narrow and expands in the posterior third. As the platform outline depends on the ontogenetic stage of development, it is possible to identify only the adult specimens with confidence.

$P$. c. costatus also resembles the stratigraphically younger Polygnathus parawebbi Chatterton, 1974; the latter has, however, deep adcarinal grooves and a sharply curved outer platform margin. For comparison with P. pseudofoliatus Wittekindt, 1966, see Klapper (1971).

Several morphotypes of this taxon were recognized in material from the Prague Basin and also from the Great Basin, Nevada (collections of M.A. Murphy at the University of California, Riverside).

Stratigraphical range. - Eifelian (early Middle Devonian). First occurrence of this taxon defines the lower boundary of the costatus Zone. The lowest occurrence of this taxon is $1.26 \mathrm{~m}$ below the base of the Choteč Limestone in the Barrandov road cut; the highest occurrence is $22 \mathrm{~m}$ (only approximate, part of the section is covered) above the base of the Choteč Limestoneat in the Jelínek mill quarry.

\section{Polygnathus pseudofoliatus Wittekindt, 1966 Figure $8 \mathrm{~A}-\mathrm{G}$}

1966 Polygnathus pseudofoliata n. sp.; Wittekindt, pp. 637, 638, pl. 2, figs 20-23 [non fig. $19=P$. eiflius].

1971 Polygnathus pseudofoliatus Wittekindt. - Klapper, pp. 63, 64, pl. 2, figs 8-13.

1975 Polygnathus pseudofoliatus Wittekindt, 1966. - Telford, pp. 50, 51, pl. 9, figs 1-12.

1977 Polygnathus pseudofoliatus Wittekindt, 1966. - Weddige, pp. 317, 318, pl. 4, figs 68-70.

1983 Polygnathus pseudofoliatus Wittekindt, 1966. Sparling, pp. 855, 856, pl. 11, figs ?S, ?T, AD, AE; pl. 12, figs K-M; pl. 13, figs X, Z, AK, AL.
1983 Polygnathus pseudofoliatus Wittekindt, 1966. Wang \& Ziegler, pl. 6, figs 14-15.

1985 Polygnathus pseudofoliatus Wittekindt. - Feist et al., pl. 1, figs ?6, 11, 17-19, 21.

1986 Polygnathus pseudofoliatus Wittekindt, 1966. - Bultynck, pl. 7, fig. 13.

1986 Polygnathus pseudofoliatus Wittekindt. - Bardashev \& Ziegler, pl. 1, figs 22-23.

1986 Polygnathus pseudofoliatus Wittekindt. - Schönlaub, pl. 5, figs 4-7, non fig. 8 [P. angusticostatus].

1989 Polygnathus pseudofoliatus Wittekindt. - Mawson \& Talent, p. 237, pl. 4, figs 16-24.

1990 Polygnathus pseudofoliatus Wittekindt, 1965. - Lazreq, pl. 2, figs 10, 11, ?12, ?13 [=P. eiflius?].

1992 Polygnathus pseudofoliatus Wittekindt, 1966. - Bardashev, pl. 5, figs 1-3, 5, 6 .

1994 Polygnathus pseudofoliatus Wittekindt. - Mawson \& Talent, pl. 2, figs 19, 20.

1995 Polygnathus pseudofoliatus Wittekindt, 1966. - Savage, p. 546, pl. 3, figs ?12, ?13, ?14, 15-17.

1995 Polygnathus pseudofoliatus Wittekindt, 1966. Sloan et al., pl. 7, figs 11, 13, non fig. 12.

1995 Polygnathus pseudofoliatus Wittekindt, 1966. Sparling, p. 1136, figs 2.1-2.4, ?2.5-2.8.

1998 Polygnathus pseudofoliatus Wittekindt. - Uyeno in Norris \& Uyeno, pp. 164, 165, pl. 11, figs 11, 20; pl. 12, figs 5, 13-15; pl. 14, figs 19-21.

1999 Polygnathus pseudofoliatus Wittekindt, 1966. Sparling, pl. 3, figs 17-19.

2003 Polygnathus pseudofoliatus Wittekindt, 1966. - Adhamian, p. 187, pl. 2, figs 9, 10.

2003 Polygnathus pseudofoliatus Wittekindt, 1966. - Morgan, pl. 3, figs 15, 16, 23.

2007 Polygnathus pseudofoliatus Wittekindt, 1965. - Benfrika et al., pl. 9, fig. 1.

Material. - 16 specimens.

Description. - Pa elements of P. pseudofoliatus from the Prague Basin have a somewhat symmetrical (outer platform is slightly wider) platform; the anterior platform margins are slightly constricted. The free blade averages $37 \%$ of the total length of the platform. Upper view: the adcarinal grooves are relatively deep, mainly in the anterior part of the platform. The degree of ornamentation of the platform shows some variation. The anterior platform is either ornamented with transverse ridges, which become weaker towards the finely nodose posterior part (Fig. 9A, B, G), or only transverse ridges are present (Fig. 9C, E). The Pa element of this taxon is characterized by a significant expansion of the posterior outer platform. Lower view: the pit is of moderate size in mature specimens and is situated between the anterior end of platform and its midlength. 

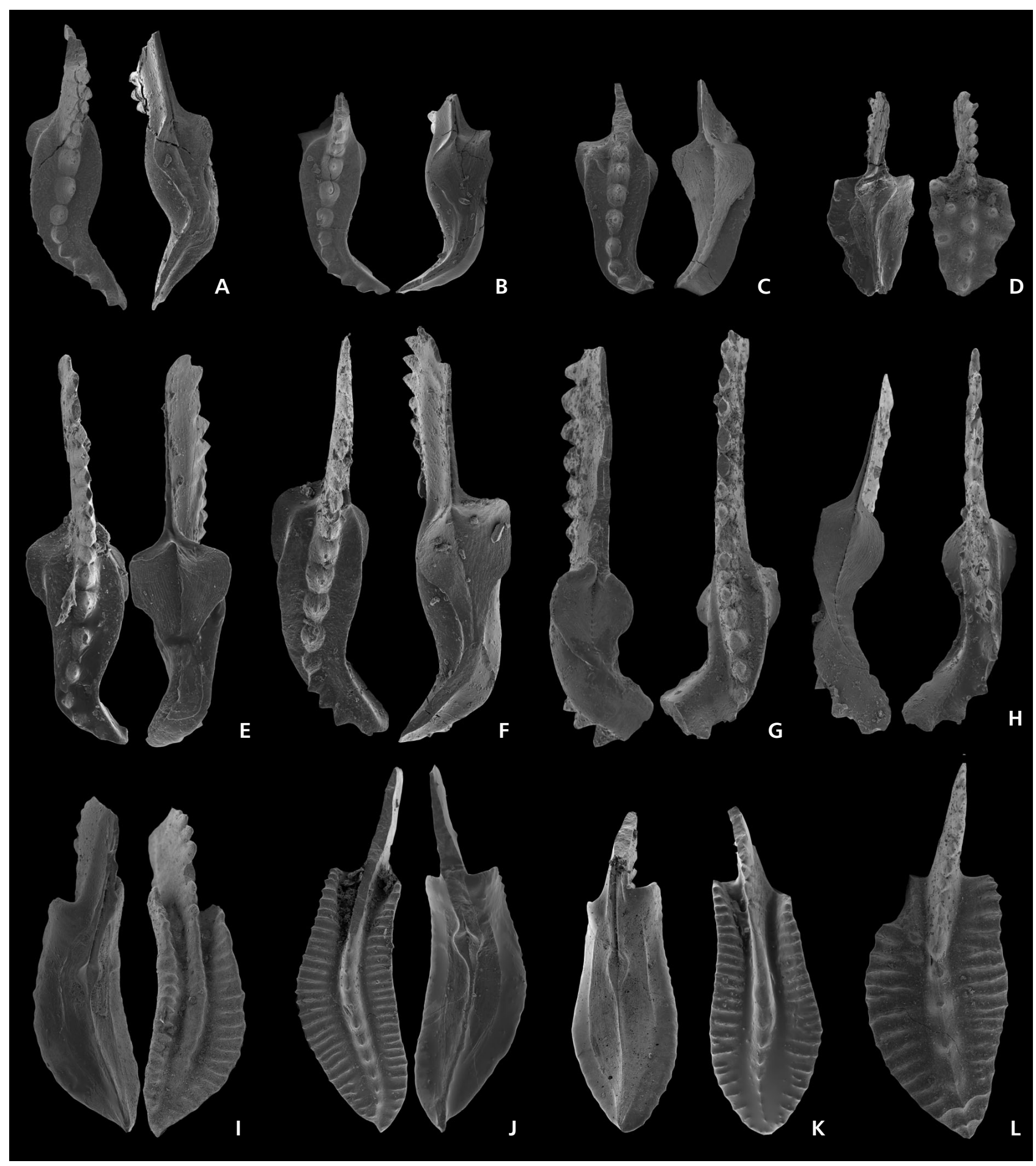

Figure 6. A-C, E-G - upper and lower views of Tortodus kockelianus kockelianus (Bischoff \& Ziegler, 1957). A-C, E-F- Jelínek mill quarry, $37 \mathrm{~m}$ above the base of the Choteč Limestone. G - Jelínek mill quarry, $35 \mathrm{~m}$ above the base of the Choteč Limestone. D - upper and lower view of Polygnathus trigonicus Bischoff \& Ziegler, 1957, Jelínek mill quarry, $35 \mathrm{~m}$ above the base of the Choteč Limestone. $\bullet \mathrm{H}-$ upper and lower view of Tortodus kockelianus australis (Jackson in Pedder et al., 1970), Jelínek mill quarry, $35 \mathrm{~m}$ above the base of the Choteč Limestone. • I-K - upper and lower views of Polygnathus costatus costatus Klapper, 1971. I - Na Škrábku quarry, 5 m above the base of the Choteč Limestone. J, K - Na Škrábku quarry, $8 \mathrm{~m}$ above the base of the Choteč Limestone. $\bullet$ L - upper view of Polygnathus sp. aff. P. trigonicus Bischoff \& Ziegler, 1957, Na Škrábku quarry, $0.4 \mathrm{~m}$ above the base of the Choteč Limestone. All magnifications are $\times 65$. 
Remarks. - Specimens figured as Fig. 8C and E may resemble $P$. c. costatus, however, the platform outline is more typical of $P$. pseudofoliatus and also the free blade to total length ratio corresponds more with $P$. pseudofoliatus. Furthermore, the transverse ridges in $P$. c. costatus are more densely spaced. Specimens figured as Fig. 8A, B and G, are similar to P. pseudofoliatus subsp. A sensu Sparkling (1995) with respect to the platform ornamentation; however, conodonts from the Prague Basin are not so constricted anteriorly, and also have better developed transverse ridges. The specimen illustrated by Sparkling (1995) in fig. 3.8, p. 1128 (P. pseudofoliatus subsp. D) is similar to the specimen from the Prague Basin figured as Fig. 8F (single specimen from Holyně locality, $11.9 \mathrm{~m}$ above the base of the Choteč Limestone) with respect to the anterior platform, which seems to slope upwards towards the free blade.

Stratigraphical range. - Late Eifelian-early Givetian (Middle Devonian). In the Prague Basin, this taxon occurs together with $P$. c. costatus and P. trigonicus. As mentioned previously, the base of the australis Zone was drawn with question mark on the basis of the presence of this taxon.

\section{Polygnathus cooperi Klapper, 1971}

\section{Polygnathus cooperi cooperi Klapper, 1971} Figure 7A-D

1971 Polygnathus linguiformis cooperi subsp. nov.; Klapper, p. 64, pl. 1, figs 12-22; pl. 2, fig. 21.

1975 Polygnathus linguiformis cooperi Klapper, 1971. Telford, pp. 44-48, pl. 8, figs 6-15.

1977 Polygnathus linguiformis cooperi Klapper 1971. Weddige, pp. 314, 315, pl. 5, figs 93, 94.

1978 Polygnathus cooperi cooperi Klapper, 1971. - Klapper et al., p. 108, pl. 2, figs 21, 22, 29, 30.

1986 Polygnathus cooperi cooperi Klapper. - Schönlaub, pl. 3, fig. 22.

1989 Polygnathus cooperi cooperi Klapper. - Mawson \& Talent, pl. 3, fig. 8

1992 Polygnathus cooperi cooperi Klapper, 1971. - Bardashev, pl. 1, fig. 2, non figs 6-10.

1992 Polygnathus cooperi cooperi Klapper, 1971. - Bardashev \& Ziegler, pl. 6, fig. ?29, non fig. 26.

1994 Polygnathus cooperi cooperi Klapper. - Mawson \& Talent, pl. 2, fig. ?4; pl. 3, fig. 6.

?1994 Polygnathus cooperi cooperi Klapper. - Talent \& Mawson, pl. 2, fig. ?18.

Material. -8 specimens.

Description. - Pa elements of $P$. c. cooperi from the Prague Basin have a slightly asymmetrical platform (the carina is situated closer to the inner margin). The adcarinal grooves are relatively shallow and broad, thus creating the characteristic broad, flat (mainly in the posterior part) appearance of the platform. The short free blade averages $18 \%$ of the total length of the platform. Upper view: widely spaced, prominent transverse ridges cover the platform, with a range of 16-20 ridges (in adult specimens). Neither the carina nor the adcarinal grooves reach the posterior end, where weak transverse ridges cross the tongue of the platform (usually only one or two ridges). Lower view: the centre of the moderate sized pit is situated at the border between the first and second quarter of the platform (in the anterior part of the platform). The keel is only slightly curved.

Remarks. - P. cooperi cooperi most closely resembles $P$. c. patulus; however, the latter can be distinguished from $P$. $c$. cooperi by having a more symmetrical development of the platform and by the absence of a tongue (the carina continues to the posterior end of the platform in $P$. c. patulus, at least in the form of nodes). The material from the Prague Basin is similar to material from New York which was assigned to a transitional form between P. c. patulus and P. c. cooperi, figured by Klapper 1971 on Pl. 1, figs 10-16. However, the platform is more asymmetrical in the latter.

Stratigraphic range. - Serotinus-lower partitus zones, late Emsian-early Eifelian (Lower-Middle Devonian). In the Prague Basin, the lowest occurrence of this taxon is $5.44 \mathrm{~m}$ below the base of the Choteč Limestone in the Na Škrábku quarry, the highest occurrence is $3.4 \mathrm{~m}$ below the base of the Choteč Limestone in the same quarry.

\section{Polygnathus trigonicus Bischoff \& Ziegler, 1957 Figure 6D}

1957 Polygnathus trigonica n. sp.; Bischoff \& Ziegler, pp. 97, 98, pl. 5, figs 1-6.

?1977 Polygnathus trigonicus Bischoff \& Ziegler 1957. Weddige, pp. 320, 321, pl. 6, figs ?98, ?99.

?1980 Polygnathus trigonicus Bischoff \& Ziegler. - Johnson et al., pl. 4, fig. ?11.

?1983 Polygnathus trigonicus Bischoff \& Ziegler, 1959. Wang \& Ziegler, pl. 7, figs ?19, ?20.

?1992 Polygnathus trigonicus Bischoff \& Ziegler, 1957. Bardashev, pl. 2, figs ?37- ?40.

1995 Polygnathus trigonicus Bischoff \& Ziegler, 1957. Savage, p. 550, pl. 2, figs 10-15.

2003 Polygnathus trigonicus Bischoff \& Ziegler 1957. Morgan, pl. 3, figs ?5, ?6, 13, 14.

2003 Polygnathus trigonicus Bischoff \& Ziegler, 1957. Pyle et al., p. 105, pl. 2, fig. 18.

Material. - 4 specimens. 


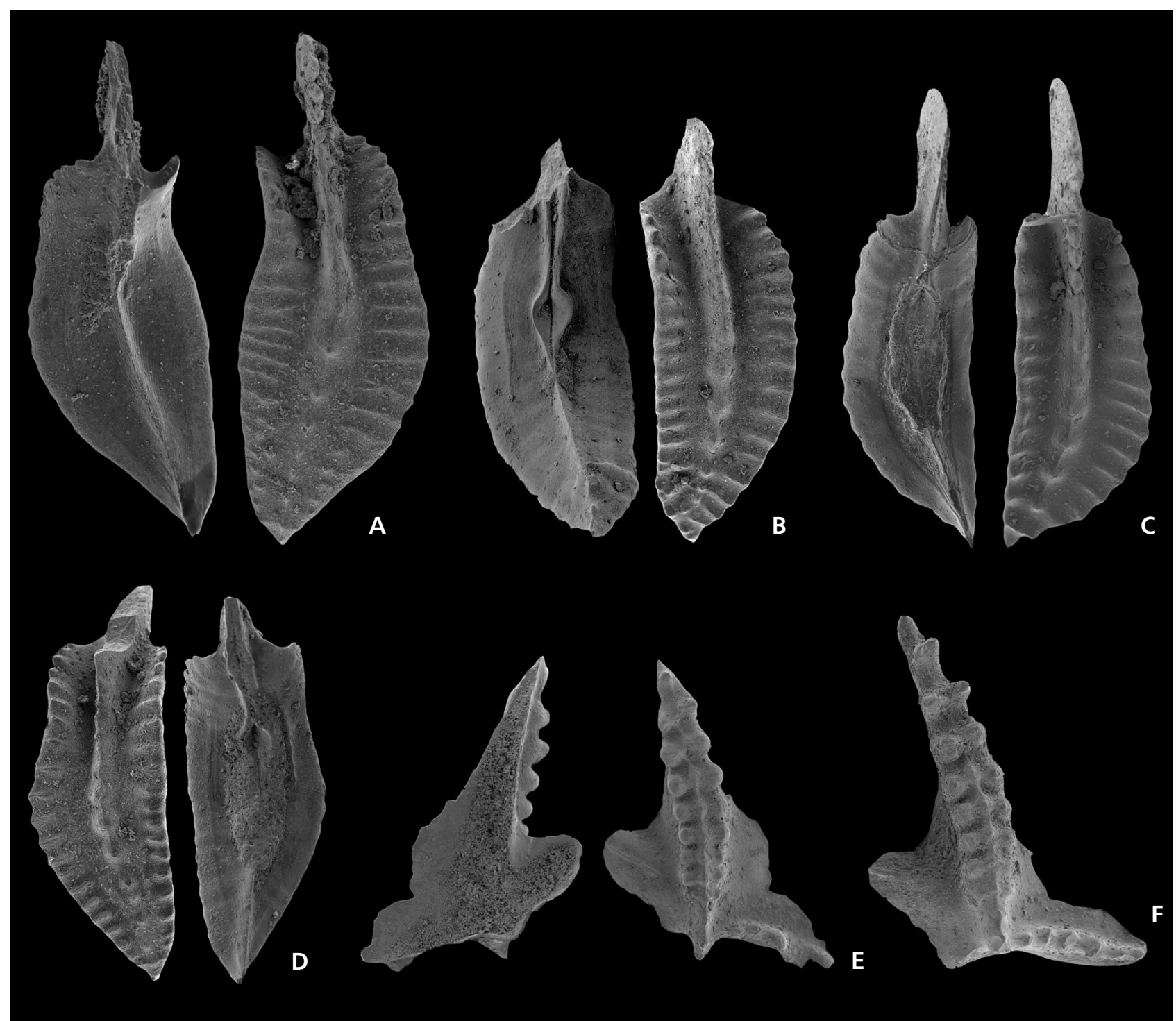

Figure 7. A-D - upper and lower views of Polygnathus cooperi cooperi Klapper, 1971. A, C-D - Prastav quarry, $4.4 \mathrm{~m}$ below the base of the Choteč Limestone. B - Na Škrábku quarry, $6.4 \mathrm{~m}$ below the base of the Choteč Limestone. • E - upper and lower view of Icriodus beckmanni sinuatus Klapper, Ziegler \& Mashkova, 1978, Jelinek mill quarry, $9.7 \mathrm{~m}$ below the base of the Choteč Limestone. • F - upper view of Icriodus beckmanni beckmanni Ziegler, 1956, Jelinek mill quarry, $9.7 \mathrm{~m}$ below the base of the Choteč Limestone. All magnifications are $\times 80$.

Descriptions. - Pa elements of $P$. trigonicus from the Prague Basin have an approximately triangular platform outline. The anterior end of the platform meets the free blade at almost a right angle. The free blade averages $45 \%$ of the total length. Upper view: Diagonal rows of nodes cover the anterior part of the platform. The adcarinal grooves are broad and very shallow. The carina is formed by a row of distinct denticles and terminates at the posterior end. Lower view: the relatively large pit with rims is located anteriorly, close to the junction of the anterior end of the platform and the free blade.

Remarks. - P. trigonicus may resemble $P$. sp. aff. P. trigonicus Klapper, 1971 in platform outline; however, the latter differs mainly by the position of the pit, which is situated closer to the midlength of the platform. The occurrence of $P$. sp. aff. P. trigonicus in the Prague Basin has been recently re-investigated.

\section{Polygnathus linguiformis Hinde, 1879}

\section{Polygnathus linguiformis cf. pinguis Weddige, 1977}

Figure 9B-C

[cf.] 1977 Polygnathus linguiformis pinguis n. ssp.; Weddige, p. 316 , pl. 5 , figs 88,89 .

[cf.] 1978 Polygnathus linguiformis pinguis Weddige, 1977. Klapper et al., pl. 2, fig. 34. 
[?] 1986 Polygnathus l. pinguis Weddige. - Bardashev \& Ziegler, pl. 1, fig. ?16.

[cf.] 1986 Polygnathus linguiformis pinguis Weddige, 1977. Bultynck, pl. 7, figs 7-9.

[cf.] 1986 Polygnathus linguiformis pinguis Weddige 1977. Ziegler \& Wang, pl. 2, fig. 7.

[cf.] 1995 Polygnathus linguiformis pinguis Weddige, 1977. Mawson et al., p. 432, pl. 3, fig. 17.

Material. - 2 specimens.

Description. - Pa elements of $P$. l. cf. pinguis have an expanded and somewhat flattened central part of the platform. Upper view: short, transverse ridges, which in the posterior third of the platform cross the tongue, ornamenting the platform. The adcarinal groove of the outer platform is deeper and wider, thus causing a flange-like development from the margin. Only one specimen preserved the free blade, which constituted $36 \%$ of the total length. Lower view: the centre of the moderate sized pit is situated just between the first and second quarter of the platform.

Remarks. - The specimens found differ from the holotype of this taxon in having a longer free blade and lacking the noded ornamentation of the platform described by Weddige (1977). Only two specimens were found, one of them incomplete; therefore further comparisons could not be made.

Stratigraphical range. - Lower-Middle Devonian, late Emsian (upper patulus Zone)-early Eifelian (lower costatus Zone). In the Prague Basin this taxon was found in $\mathrm{Na}$ Škrábku quarry, $0.17 \mathrm{~m}$ above the bed that yielded Polygnathus sp. aff. P. trigonicus.

\section{Genus Tortodus Weddige, 1977}

Type species. - Tortodus kockelianus (Bischoff \& Ziegler, 1957).

\section{Tortodus kockelianus (Bischoff \& Ziegler, 1957)}

Diagnosis. - See original diagnosis in Bischoff \& Ziegler (1957).
Tortodus kockelianus kockelianus (Bischoff \& Ziegler, 1957)

Figure 6 A-C, E-G

1957 Polygnathus kockeliana n. sp.; Bischoff \& Ziegler, p. 91, pl. 2, figs 1-8, non 9-12 [= T. k. australis].

1977 Tortodus kockelianus kockelianus (Bischoff \& Ziegler, 1957). - Weddige, pp. 328, 329, pl. 3, fig. 52.

1983 Tortodus kockelianus kockelianus (Bischoff \& Ziegler, 1957). - Wang \& Ziegler, pl. 8, figs 12, 13.

1985 Tortodus kockelianus kockelianus (Bischoff \& Ziegler). - Feist et al., pl. 1, figs ?10, 26.

1986 Tortodus kockelianus kockelianus (Bischoff \& Ziegler). - Bultynck, pl. 7, fig. 19.

1986 Tortodus kockelianus kockelianus (Bischoff \& Ziegler). - Schönlaub, pl. 5, figs 20-23.

1986 Tortodus kockelianus kockelianus (Bischoff \& Ziegler, 1957). - Ziegler \& Wang, pl. 1, figs 20, 21.

?1989 Tortodus kockelianus kockelianus (Bischoff \& Ziegler). - Mawson \& Talent, pl. 6, fig. ?19.

1990 Tortodus kockelianus kockelianus (Bischoff \& Ziegler, 1957). - Lazreq, pl. 2, figs 1-3, ?4.

1992 Tortodus kockelianus kockelianus (Bischoff \& Ziegler, 1957). - Bardashev, pl. 4, figs 18, 22, 23, 27, 28 , $29,32$.

1995 Tortodus kockelianus kockelianus (Bischoff \& Ziegler, 1957). - Savage, pp. 552, 553, pl. 6, figs 1-6.

2003 Tortodus kockelianus kockelianus (Bischoff \& Ziegler 1957). - Morgan, pl. 2, figs 13-24.

2003 Tortodus kockelianus kockelianus Bischoff \& Ziegler 1957. - Pyle et al., p. 105, pl. 2, figs 21, 22.

Material. - 11 specimens.

Description. - The Pa elements of T. $k$. kockelianus from the Prague Basin have a posteriorly twisted, smooth platform, which bears only one row of denticles, which are discrete and conical shaped. The free blade averages $40 \%$ of the total length. The platform gradually widens towards the anterior end. The flared basal cavity is situated in the anterior part, close to the junction of the platform and the free blade.

Remarks. - T. k. kockelianus is similar to T. k. australis (see Jackson in Pedder et al. 1970); however, the latter can be distinguished by the more restricted platform development

Figure 8. A-G-upper and lower views of Polygnathus pseudofoliatus Wittekindt, 1966. A, B, D, E-Barrandov road cut section, 5 m above the base of the Choteč Limestone. C - Holyně section, $12.2 \mathrm{~m}$ above the base of the Choteč Limestone. F-Holyně section, $11.9 \mathrm{~m}$ above the base of the Choteč Limestone. G - Barrandov road cut, $4.5 \mathrm{~m}$ above the base of the Choteč Limestone. $\bullet$ H, I - upper and lower views of Polygnathus linguiformis bultyncki Weddige, 1977. H - Jelínek mill quarry, $4.7 \mathrm{~m}$ below the base of the Choteč Limestone. I - Jelínek mill quarry, $9.7 \mathrm{~m}$ below the base of the Choteč Limestone. - J - upper and lower view of Polygnathus serotinus Telford, 1975, Jelinek mill quarry, 9.7 m below the base of the Choteč Limestone. All magnifications are $\times 57$. 

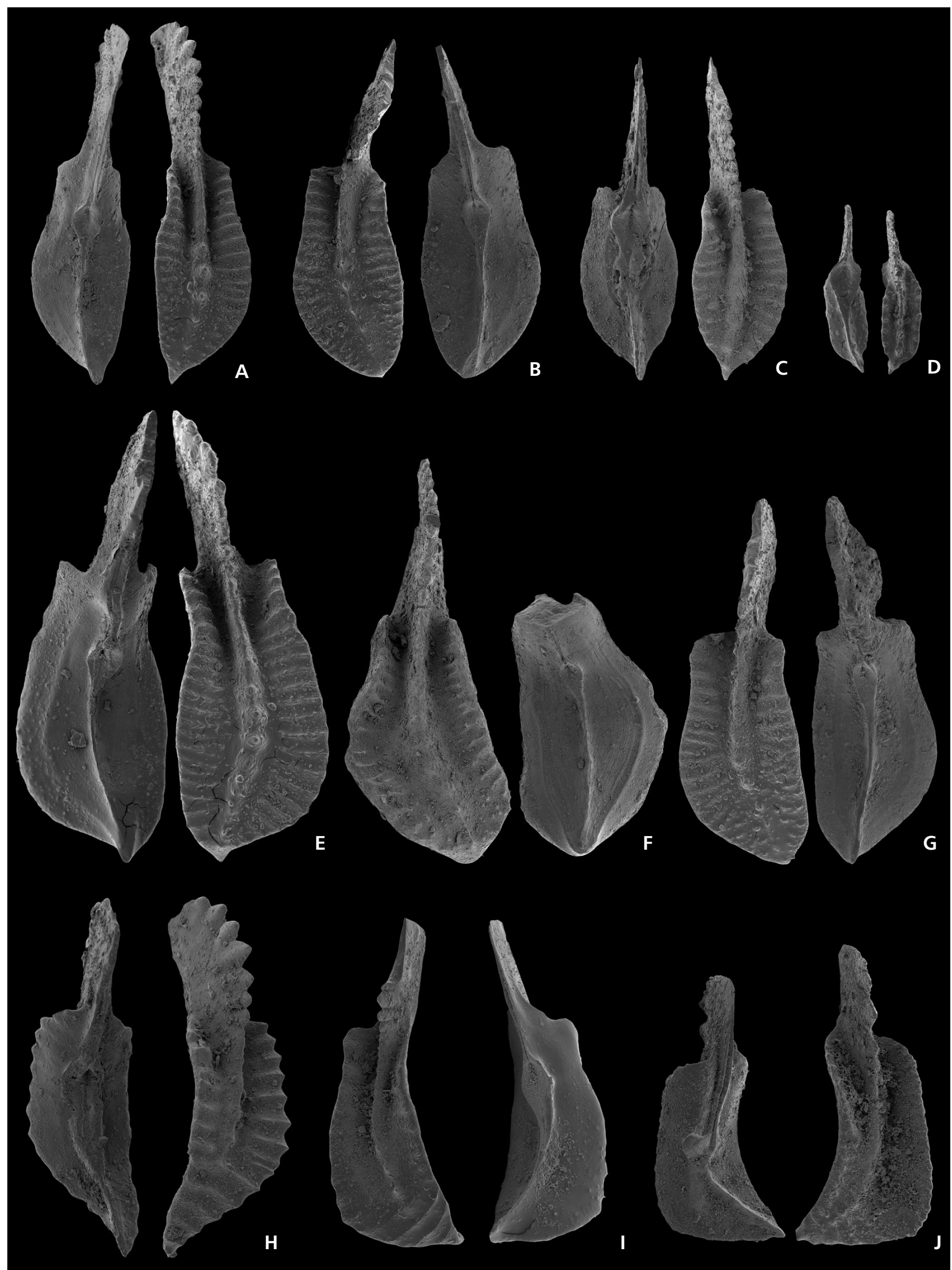


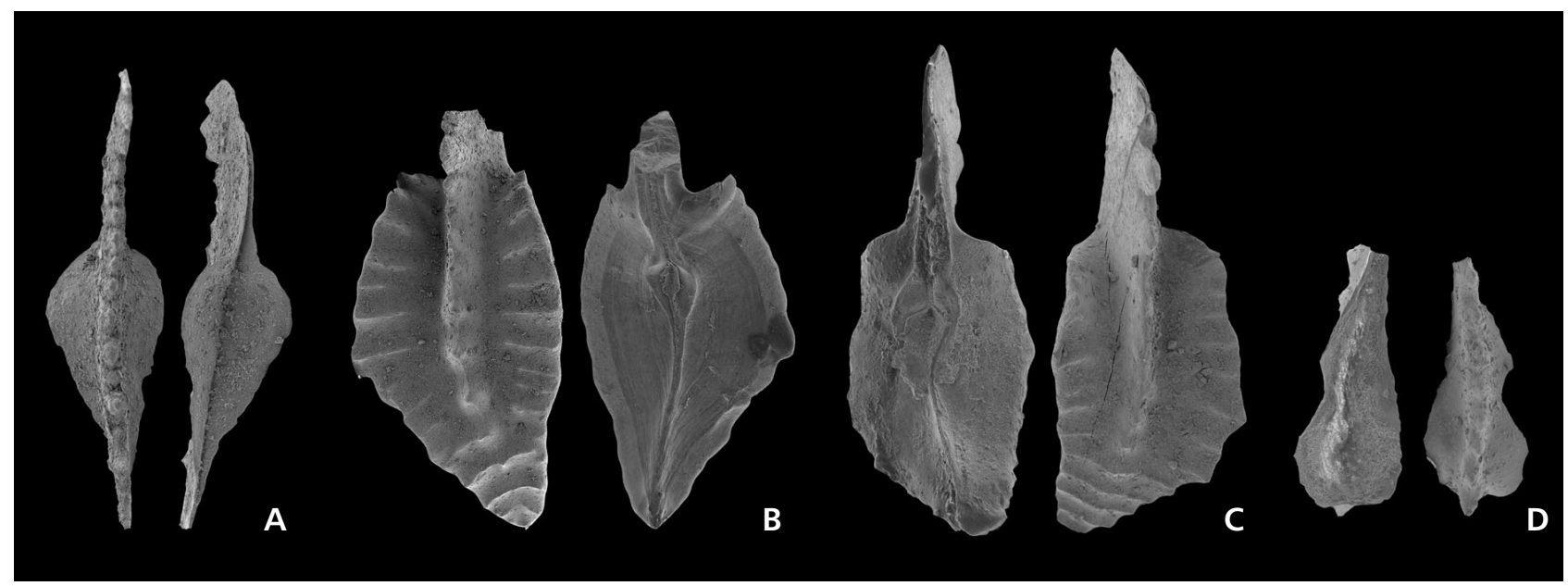

Figure 9. A - upper and lower view of Ozarkodina carinthiaca (Schulze, 1968), Jelínek mill quarry, $9.7 \mathrm{~m}$ below the base of the Choteč Limestone. - B, C - upper and lower views of Polygnathus linguiformis pinguis Weddige, 1977. B - Na Škrábku quarry, $0.65 \mathrm{~m}$ above the base of the Choteč Limestone. C - Na Škrábku quarry, $0.6 \mathrm{~m}$ above the base of the Choteč Limestone. • D - upper and lower view of Pelekysgnathus sp., Na Škrábku quarry, $0.65 \mathrm{~m}$ above the base of the Choteč Limestone. All magnifications are $\times 56$.

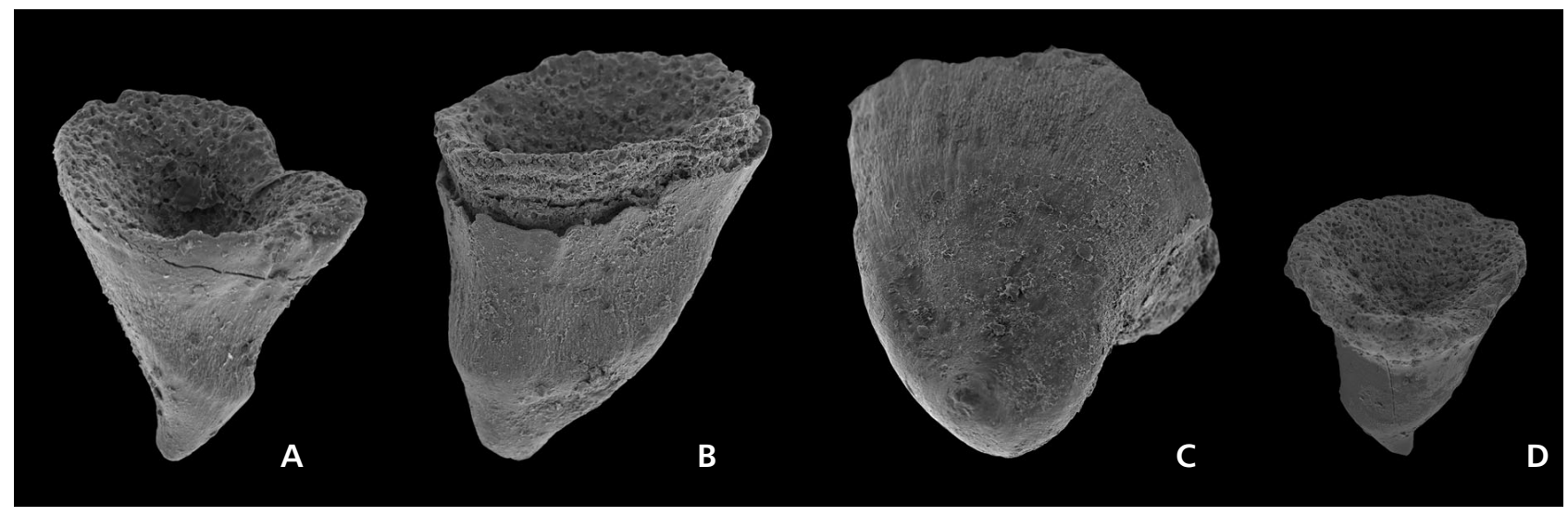

Figure 10. A-D - lateral views of Pseudooneotodus beckmanni (Bischoff \& Sannemann, 1958). A - Na Škrábku quarry, $4.5 \mathrm{~m}$ below the base of the Choteč Limestone. B - Barrandov road cut, $12 \mathrm{~m}$ below the base of the Choteč Limestone. C - Jelínek mill quarry, $7.7 \mathrm{~m}$ below the base of the Choteč Limestone. D - Jelinek mill quarry, $9.7 \mathrm{~m}$ below the base of the Choteč Limestone. All magnifications are $\times 144$.

(the platform is much narrower in T. k. australis). Transitional forms between these two subspecies have been observed. The limited material available from the Prague Basin did not allow further comparison between these subspecies.

Stratigraphical range. - Kockelianus Zone, Eifelian (Middle Devonian). In the Prague Basin this taxon occurs together with $P$. trigonicus.

\section{Tortodus kockelianus australis (Jackson in Pedder} et al., 1970)

Figure $6 \mathrm{H}$

1977 Tortodus kockelianus australis (Jackson, 1970). Weddige, p. 328, pl. 3, fig. 52.

1983 Tortodus kockelianus australis (Jackson, 1970). Wang \& Ziegler, pl. 8, figs 17-18.
1986 Tortodus kockelianus australis Weddige. - Schönlaub, pl. 5, figs 15-19.

1986 Tortodus kockelianus australis (Jackson, 1970). - Ziegler \& Wang, pl. 1, fig. 22.

?1989 Tortodus kockelianus australis (Jackson). - Mawson \& Talent, pl. 6, fig. ?18.

1992 Tortodus kockelianus australis (Jackson, 1970). Bardashev, pl. 4, figs ?26, ?30, 31?, ?17, 16, 24.

1995 Tortodus kockelianus australis (Jackson in Pedder et al., 1970). - Savage, p. 554, pl. 6, figs 7-9.

2003 Tortodus kockelianus Bischoff \& Ziegler. - Pyle et al., pl. 2, figs 19, 20.

Material. - 2 specimens.

Stratigraphical range. - Australis Zone, Eifelian (Middle Devonian). In the Prague Basin this taxon occurs together with $P$. trigonicus. 


\section{Acknowledgements}

This work was supported by grants from the Grant Agency of the Academy of Science, the Czech Republic (KJB 307020602), the Czech-American Cooperation Program (Kontakt ME08011), CGS grant (3325) and the NAP0001 (subproject of IGCP 497). The reviewers, L. Slavík (Academy of Science, Prague) and N. Savage (University of Oregon, Eugene), are deeply acknowledged for their constructive criticism and helpful suggestions, which improved the final draft significantly. J. Hladil, G. Klapper, $\breve{S}$. Manda and O. Lehnert are thanked for critical reading of the manuscript and valuable comments. The help of J. Frýda, R. Vodrážka, L. Slavík, L. Koptíková and M. Valent in the field was deeply appreciated. The author also gratefully acknowledges the Palaeontological Association for the Sepkoski Grant award which allowed the study to proceed. Additionally, N. Hrdličková is acknowledged for technical assistance during laboratory work. This paper represents a contribution to IGCP 499.

\section{References}

Adhamian, A. 2003. Middle Devonian (Givetian) conodont biostratigraphy in the Soh area, north of Esfahan, Iran. Courier Forschungsinstitut Senckenberg 245, 183-193.

BARDASHEV, I.A. \& ZIEGLER, W. 1986. Conodonts from a Middle Devonian section in Tadzhikistan (Kalagach Fm., Middle Asia, USSR). Courier Forschungsinstitute Senckenberg 75, 65-78 [date of imprint, 1985].

BARDASHEV, I.A. 1992. Conodont stratigraphy of Middle Asian Middle Devonian. Courier Forschungsinstitute Senckenberg 154, 31-83.

BARDASHEV, I.A. \& ZIEGLER, W. 1992. Conodont biostratigraphy of Lower Devonian deposits of the Shishkat section (southern Tien-Shan, Middle Asia). Courier Forschungsinstitute Senckenberg 154, 1-29.

Belka, Z., KaufmanN, B. \& BUltynck, P. 1997. Conodontbased quantitative biostratigraphy for the Eifelian of the eastern Anti-Atlas, Morocco. Geological Society of America Bulletin 109(6), 643-651.

DO1 10.1130/0016-7606(1997)109<0643:CBQBFT>2.3.CO;2

BENFRIKA, EL M. \& BULTYNCK, P. 2003. Lower to Middle Devonian conodonts from the Oued Cherrat area and its southern extension (North-Western Meseta, Morocco). Courier Forschungsinstitute Senckenberg 242, 209-215.

BENFRIKA, El M., BULTYNCK, P. \& El HASSANI, A. 2007. Upper Silurian to Middle Devonian conodont faunas from the Rabat Tiflet area (northwestern Moroccan Meseta). Geological Quarterly 51(4), 393-406.

BISCHOFF, G. \& ZIEGLER, W. 1957. Die Conodontenchronologie des Mitteldevons und des tiefsten Oberdevons. Abhandlungen des Hessischen Landesamtes für Bodenforschung 22, 1-136.

BONCHEVA, I. 1992. Emsian representatives of the conodont genus Polygnathus Hinde, 1879 from Southwest Bulgaria. Geologica Balcanica 22(2), 33-45.

BUDIL, P. 1995. Demonstrations of the Kačák event (Middle Devonian, uppermost Eifelian) at some Barrandian localities. Věstník Českého geologického ústavu 70(4), 1-19.

BUlTYNCK, P. 1986. Lower Devonian (Emsian) - Middle Devonian (Eifelian and lowermost Givetian) conodont successions from the Ma'der and Tafilalt, southern Morocco. Courier Forschungsinstitute Senckenberg 75, 261-256 [date of imprint, 1985].
BUGGISCH, W. \& MANN, U. 2004. Carbon isotope stratigraphy of Lochkovian to Eifelian limestones from the Devonian of central and southern Europe. International Journal of Earth Sciences 93, 521-541.

CHLUPÁČ, I. 1959. Faciální vývoj a biostratigrafie břidlic dalejských a vápenců hlubočepských (eifel) ve středočeském devonu. Sborník Ústředního ústavu geologického 25, 445-511.

CHLUPÁČ, I. 1982. Preliminary submission for Lower-Middle Devonian boundary stratotype in the Barrandian area. Courier Forschungsinstitute Senckenberg 55, 85-96.

CHLUPÁČ, I. 1985. Comments on the Lower-Middle Devonian boundary. Courier Forschungsinstitute Senckenberg 75, 389-400.

ChLUPÁČ, I., LUKEŠ, P. \& ZIKMUNDOVÁ, J. 1977. Barrandian 1977. A field trip Guidebook, Field Conference of the International Subcommission on Devonian Stratigraphy. 23 pp. Central Geological Survey, Praha.

ChluPÁČ, I., LUKEŠ, P. \& ZiKMundovÁ, J. 1979. The LowerMiddle Devonian boundary beds in the Barrandian area, Czechoslovakia. Geologica et Palaeontologica 13, 125-156.

CHLUPÁČ, I. \& KUKAL, Z. 1986. Reflection of possible global Devonian events in the Barrandian area, C.S.S.R. Lecture Note in Earth Sciences, 169-179.

ChLuPÁČ, I. \& KuKaL, Z. 1988. Possible global events and the stratigraphy of the Palaeozoic of the Barrandian (CambrianMiddle Devonian, Czechoslovakia). Sborník geologických věd, Geologie 43, 83-146.

EllwoOd, B.B., GARCÍA-AlCADE, J.L., El HASSANI, A., HLADIL, J., Soto, F.M., TruYÓls-MASSONI, M., WedDige, K. \& KoptíKOVÁ, L. 2006. Stratigraphy of the Middle Devonian boundary: Formal definition of the susceptibility magnetostratotype in Germany with comparisons to sections in the Czech Republic, Morocco and Spain. Tectonophysics 418, 31-49. DOI 10.1016/j.tecto.2005.12.012

FEIST, R., SCHÖNLAUB, H.P. \& BULTYNCK, P. 1985. Faciès et biostratigraphie (conodonts) du passage Dévonien inférieurmoyen dans la Montagne. Noire (France). Hercynica 1(2), 81-97.

GALle, A. \& HLADIL, J. 1991. Lower Palaeozoic corals of Bohemia and Moravia. $6^{\text {th }}$ Fossil Cnidaria Guideooks to Field Trips $B 3,1-83$.

HAVLÍČEK, V. \& KUKAL, Z. 1990. Sedimentology, benthic communities, and brachiopods in the Suchomasty (Dalejan) and Acanthopyge (Eifelian) Limestones of the Koněprusy area (Czechoslovakia). Sborník geologických věd, Paleontologie 31, 105-205.

HINDE, G.J. 1879. On conodonts from the Chazy and Cincinnati Group of the Cambro-Silurian, and from the Hamilton and Genesse-Shale divisions of Devonian, in Canada and the United States. Quarterly Journal of the Geological Society of London 35, 351-369. DOI 10.1144/GSL.JGS.1879.035.01-04.23

HLADIL, J. \& KALVODA, J. 1993. Extinction and recovery successions of the Devonian marine shoals; the Eifelian-Givetian and Frasnian-Famennian events in Moravia and Bohemia. Bulletin of the Czech Geological Survey 68(4), 13-23.

JOHNSON, J.G., KLAPPER, G. \& TROJAN, W.R. 1980. Brachiopod and conodont succession in the Devonian of the northern Antelope Range, central Nevada. Geologica et Palaeontologica 14, 77-116.

KLAPPER, G. 1971. Sequence within the conodont genus Polygnathus in the New York lower Middle Devonian. Geologica et Palaeontologica 5, 59-79.

KLAPPER, G. 1977a. Lower-Middle Devonian boundary conodont 
sequence in the Barrandian area of Czechoslovakia. Časopis pro mineralogii a geologii 22(4), 401-410.

KLAPPER, G. 1977b. Lower and Middle Devonian Conodont Sequence in Central Nevada. University of California, Riverside Campus Museum Contributions 4, 33-55

KLAPPER, G., ZIEGLER, W. \& MASHKOVA, T.V. 1978. Conodonts and correlation of Lower-Middle Devonian boundary beds in the Barrandian area of Czechoslovakia. Geologica et Palaeontologica 12, 103-116.

KLAPPER, G. \& JOHNSON, J.G. 1980. Endemism and dispersal of Devonian conodonts. Journal of Palaeontology 54(2), 400-455.

KoptíKOVÁ, L. (accepted). Precise position of the Basal Choteč event and evolution of sedimentary environment close above the Lower-Middle Devonian boundary: magnetic susceptibility, gamma-ray spectrometric, lithological and geochemical record in Prague Synform (Czech Republic). Palaeogeography, Palaeoclimatology, Palaeoecology.

LAZREQ, N. 1990. Devonian conodonts from central Morocco. Courier Forschungsinstitute Senckenberg 118, 65-79.

LUKEŠ, P. 1989. Tentaculites from the Lower-Middle Devonian section in Prague-Barrandov. Věstník Ústředního ústavu geologického 64(4), 194-204.

MAWSON, R. \& TALENT, J.A. 1989. Late Emsian-Givetian stratigraphy and conodont biofacies - carbonate slope and offshore shoal to sheltered lagoon and nearshore carbonate ramp - Broken River, north Queensland, Australia. Courier Forschungsinstitute Senckenberg 117, 205-259.

MAWSON, R. \& TALENT, J.A. 1994. The Tamworth Group (Mid-Devonian) at Attunga, New South Wales: Conodont Data Inferred Ages. Courier Forschungsinstitute Senckenberg 168, 37-59.

MAWSON, R., TALENT, J.A. \& FUREY-GREIG, T.M. 1995. Coincident conodont faunas (late Emsian) from the Yarrol and Tamworth belts of northern New South Wales and central Queensland. Courier Forschungsinstitut Senckenberg 182, 421-445.

MORGAN, R.M. 2003. Middle Devonian (kockelianus-ensensis Zone) conodonts from the Moore Creek Limestone, N. S. W., Australia. Courier Forschungsinstitut Senckenberg 242, 285-299.

NORRIS, A.W. \& UYENO, T.T. 1998. Middle Devonian Brachiopods, Conodonts, Stratigraphy, and Transgressive-Regressive Cycles, Pine Point Area, South of Great Slave Lake, District of Mackenzie, Northwest Terrifories. Geological Survey of Canada Bulletin 522, 1-191.

PEDDER, A.E.H., JACKSON, J.A. \& ELLENOR, D.W. 1970. An interim account of the Middle Devonian Timor Limestone of northeastern New South Wales. Proccedings of the Linnean Society of New South Wales 94, 242-272.

PerRY, D.G., KLAPPER, G. \& LENZ, A.C. 1974. Age of the Ogilvie Formation (Devonian), Northern Yukon: Based primarily on the occurrence of brachiopods and conodonts. Canadian Journal of Earth Sciences 11(8), 1055-1097. DO1 10.1139/e74-104

PHILIP, G.M. \& JACKSON, J.H. 1973. The sequence of Lower and Middle Devonian conodont faunas in eastern Australia, 248-254. In Stratigrafiya nizhnego i sredneho devona. simpoziuma Granitse Silura i Devona i Stratigrafii niznego i Srednego Devona.

PYLE, L.J., ORCHARD, M.J., BARNES, C.R. \& LANDRY, M.L. 2003. Conodont biostratigraphy of the Lower to Middle Devonian Deserters Formation (new), Road River Group, northeastern British Columbia. Canadian Journal of Earth Sciences 40, 99-113. DOI 10.1139/e02-095

SAVAGE, N. 1995. Middle Devonian conodonts from the Wadleigh
Limestone, southeastern Alaska. Journal of Paleontology 69(3), 540-555.

SCHÖNLAUB, H.P. 1986. Devonian conodonts from section Oberbubach II in the Carnic Alps (Austria). Courier Forschungsinstitute Senckenberg 75, 353-374 [date of imprint, 1985].

SLOAN, T.R., TALENT, J.A., MAWSON, R., SIMPSON, A.J., BROCK, G.A., ENGelbretsen, M., Jell, J.S., AUnG, A.K., PFAFFenRitTer, C., TrotTer, J. \& Withnall, I.W. 1995. Conodont data from Silurian-Middle Devonian carbonate fans, debris flows, allochthonous blocks and adjacent autochthonous platform margins: Broken River and Camel Creek areas, north Queensland, Australia. Courier Forschungsinstitut Senckenberg $182,1-77$.

SPARLING, D.R. 1983. Conodont biostratigraphy and biofacies of lower Middle Devonian limestones, north-central Ohio. Journal of Paleontology 57(4), 825-864.

SPARLING, D.R. 1995. Conodonts from the Middle Devonian Plum Brook Shale of north-central Ohio. Journal of Paleontology 69(6), 1123-1139.

SPARLING, D.R. 1999. Conodonts from the Prout Dolomite of north-central Ohio and Givetian (upper Middle Devonian) correlation problems. Journal of Paleontology 7, 892-907.

SVOBODA, J. \& PRANTL, F. 1948. O stratigrafiii a tektonice staršího paleozoika v okolí Chýnice. Sborník Státního geologického ústavu 15, 1-39.

SVOBODA, J. \& PRANTL, F. 1953. O stratigrafii a tektonice staršího paleozoika mezi Srbskem a Svatým Janem pod Skalou. Sborník Ústředního ústavu geologického 20, 205-275.

SVOBODA, J. \& PRANTL, F. 1955. O stratigrafii a tektonice staršího paleozoika v širším okolí Karlštejna. Sborník Ústředního ústavu geologického 21(1), 519-596.

TALENT, J.A. \& MAWSON, R. 1994. Conodonts in relation to age and environmental framework of the Burdekin Basin (Mid-Devonian), North-Eastern Australia. Courier Forschungsinstitut Senckenberg 168, 61-81.

TELFORD, P.G. 1975. Lower and Middle Devonian conodonts from the Broken River Embayment, North Queensland, Australia. Special Papers in Palaeontology 15, 1-96.

WANG, C.Y. \& ZIEGLER, W. 1983. Devonian conodont biostratigraphy of Guangxi, South China, and the correlation with Europe. Geologica et Palaeontologica 17, 75-107.

WeDDIGE, K. 1977. Die Conodonten der Eifel-Stufe im Typusgebiet und in benachbarten Faciesgebieten. Senckenbergiana lethaea 58(4/5), 271-419.

WedDIGE, K., WeRnER, R. \& ZIEGLER, W. 1979. The EmsianEifelian boundary. An attempt at correlation between the Eifel and Ardennes regions. Newsletter on Stratigraphy 8, 159-169.

WEDDIGE, K. \& ZIEGLER, W. 1987. Lithic and faunistic ratios of conodont sample data as facial indicators, 333-340. In AUSTIN, R. (ed.) Conodonts: Investigative Techniques and Applications, British Micropalaeontological Society Series, London.

WiTTEKINDT, H. 1966. Zur Conodontenchronologie des Mitteldevons. Fortschritte in der Geologie von Rheinland und Westfalen 9, 621-646 [date of imprint, 1965].

ZIEGLER, W. \& WANG, C.Y. 1986. Sihongshan Section, a regional reference section for the Lower-Middle and Middle-Upper Devonian Boundaries in the East Asia. Courier Forschungsinstitute Senckenberg 75, 17-38 [date of imprint, 1985].

ZUSKOVÁ, J. 1991. Conodont faunas from the Lower/Middle Devonian section in Praha-Barrandov. Věstník Ústředního ústavu geologického 66(2), 107-112. 